
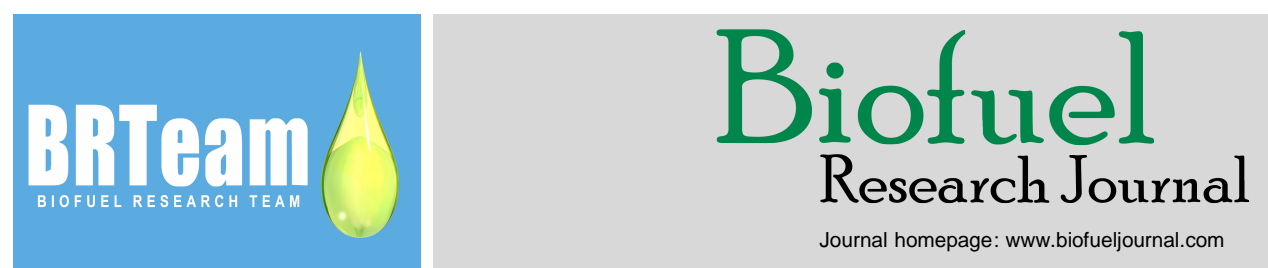

Journal homepage: www.biofueljournal.com

Review Paper

\title{
Biorefinery perspectives of microbial electrolysis cells (MECs) for hydrogen and valuable chemicals production through wastewater treatment
}

\author{
Abudukeremu Kadier ${ }^{1,2}$, Pratiksha Jain ${ }^{3,4}$, Bin Lai ${ }^{5}$, Mohd Sahaid Kali1 ${ }^{1,2}$, Sanath Kondaveeti ${ }^{6}$, Khulood Fahad Saud \\ Alabbosh $^{7}$, Ibrahim M Abu-Reesh ${ }^{8}$, Gunda Mohanakrishna ${ }^{8, *}$ \\ ${ }^{1}$ Department of Chemical and Process Engineering, Faculty of Engineering and Built Environment, National University of Malaysia (UKM), 43600 UKM \\ Bangi, Selangor, Malaysia. \\ ${ }^{2}$ Research Centre for Sustainable Process Technology (CESPRO), Faculty of Engineering and Built Environment, National University of Malaysia (UKM), \\ 43600 UKM Bangi, Selangor, Malaysia. \\ ${ }^{3}$ TERI University, 10, Institutional Area, Vasant Kunj, New Delhi - 110070, India. \\ ${ }^{4}$ The Energy and Resources Institute (TERI), India Habitat Center, Lodhi Road, New Delhi - 110003, India. \\ ${ }^{5}$ Department of Solar Materials, Helmholtz Centre for Environmental Research - UFZ, 04318 Leipzig, Germany. \\ ${ }^{6}$ Department of Chemical Engineering, Konkuk University, Seoul 05029, Republic of Korea. \\ ${ }^{7}$ School of Biosciences and Biotechnology, Faculty of Science and Technology, National University of Malaysia (UKM), 43600 UKM Bangi, Selangor, Malaysia. \\ ${ }^{8}$ Department of Chemical Engineering, College of Engineering, Qatar University, P O Box. 2713, Doha, Qatar.
}

\section{HIGHLIGHTS}

$>$ Critically reviews the niche areas, fundamentals, and advantages of the MEC technology.

$>$ Comprehensively quantifies and analyses performance of MEC based on integrated approaches.

$>$ Discuss existing challenges and limitations of MEC platform for biorefinery applications.

\section{GRAPHICAL ABSTRACT}

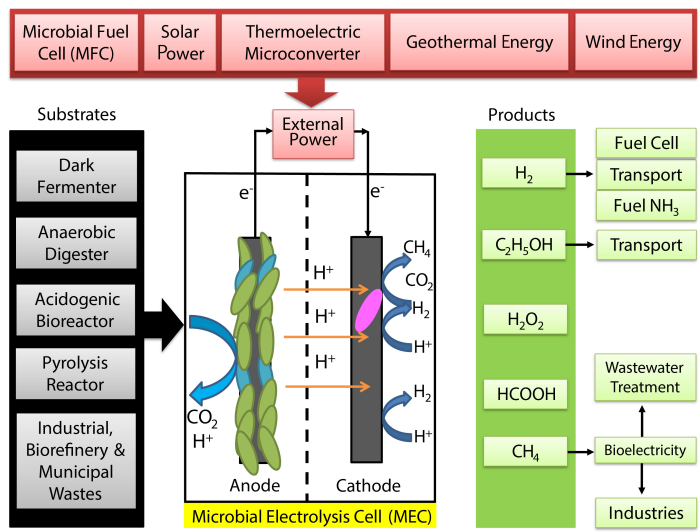

\section{ARTICLE INFO}

\section{Article history:}

Received 24 April 2019

Received in revised form 13 October 2019

Accepted 16 December 2019

Available online 1 March 2020

\section{Keywords:}

Biohydrogen production

Microbial electrolysis cell (MEC)

Wastewater treatment

Dark fermentation

Substrate degradation

\begin{abstract}
The degradation of waste organics through microbial electrolysis cell (MEC) generates hydrogen $\left(\mathrm{H}_{2}\right)$ gas in an economically efficient way. MEC is known as the advanced concept of the microbial fuel cell (MFC) but requires a minor amount of supplementary electrical energy to produce $\mathrm{H}_{2}$ in the cathode microenvironment. Different bio/processes could be integrated to generate additional energy from the substrate used in MECs, which would make the whole process more sustainable. On the other hand, the energy required to drive the MEC mechanism could be harvested from renewable energy sources. These integrations could advance the efficiency and economic feasibility of the whole process. The present review critically discusses all the integrations investigated to date with MECs such as MFCs, anaerobic digestion, microbial desalination cells, membrane bioreactors, solar energy harvesting systems, etc. Energy generating non-biological and eco-friendly processes (such as dyesensitized solar cells and thermoelectric microconverters) which could also be integrated with MECs, are also presented and reviewed. Achieving a comprehensive understanding about MEC integration could help with developing advanced biorefineries towards more sustainable energy management. Finally, the challenges related to the scaling up of these processes are also scrutinized with the aim to identify the practical hurdles faced in the MEC processes.
\end{abstract}

(C2020 BRTeam. All rights reserved.

* Corresponding author at: Tel.: +974-33084811

E-mail address: gmohanak@yahoo.com ; gmohanak@gmail.com

Please cite this article as: Kadier A., Jain P., Lai B., Kalil M.S., Kondaveeti S., Alabbosh K.F.S., Abu-Reesh I.M., Mohanakrishna G. Biorefinery perspectives of microbial electrolysis cells (MECs) for hydrogen and valuable chemicals production through wastewater treatment. Biofuel Research Journal 25 (2020) 1128-1142. DOI: 10.18331/BRJ2020.7.1.5 


\section{Contents}

1. Introduction.

2. Fundamentals of microbial electrolysis cells.

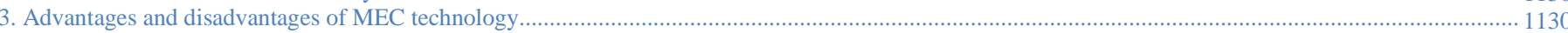

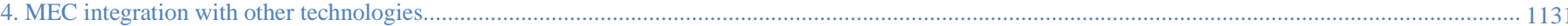

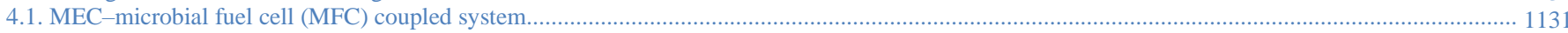

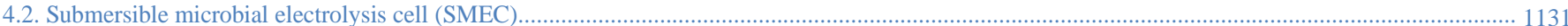

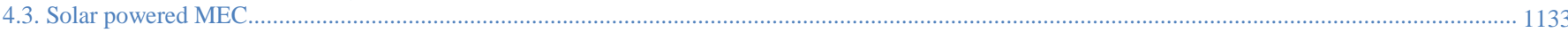

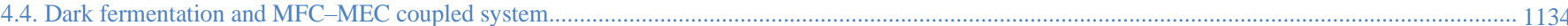

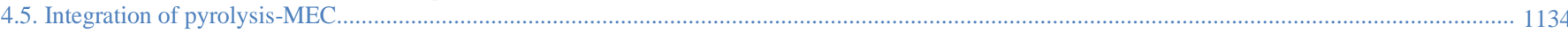

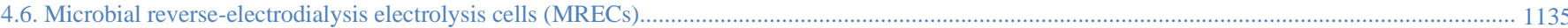

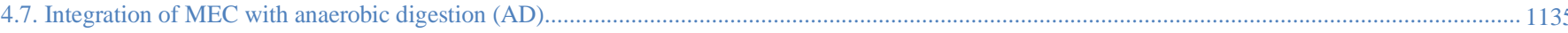

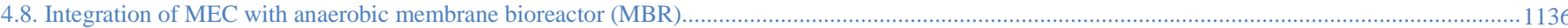

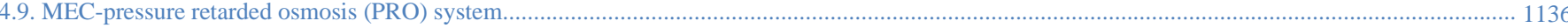

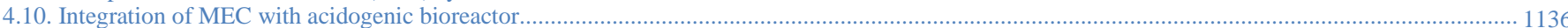

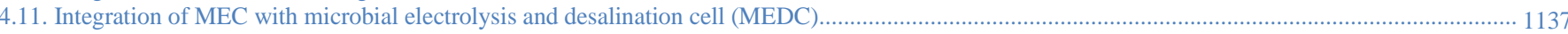

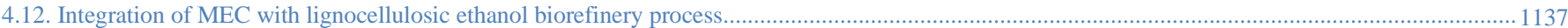

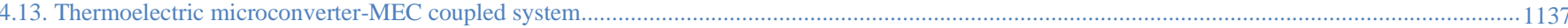

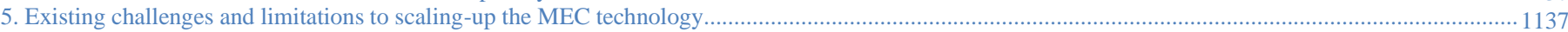

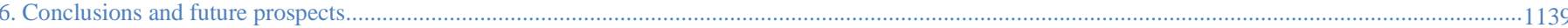

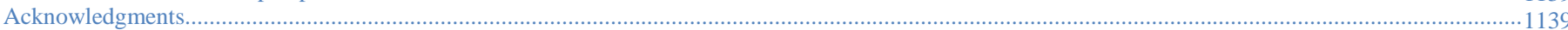

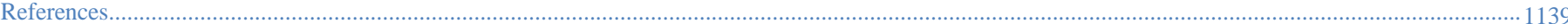

\begin{tabular}{ll|} 
Abbreviations & \\
AD & Anaerobic digestion \\
AEM & Anion exchange membrane \\
AnEMBR & Anaerobic electrochemical membrane bioreactor \\
BES & Bio-electrochemical system \\
BEH & Bio-electrohydrolysis \\
BOD & Biological oxygen demand \\
BPEC & Bio-photo-electrochemical cell \\
BPM & Bipolar membrane \\
CF & Carbon felt \\
CNP & Carbon nanopowder \\
CEM & Cation exchange membrane \\
COD & Chemical oxygen demand \\
CSTR & Continuous stirred tank reactor \\
DrF & Dark fermenter \\
DSSC & Dye-sensitized solar cell \\
FO & Forward osmosis \\
GHG & Greenhouse gas \\
HBR & Hydrogen bioreactor \\
HPR & Hydrogen production rate \\
MBR & Membrane bioreactor \\
MDC & Microbial desalination cell \\
MEC & Microbial electrolysis cell \\
MEDC & Microbial electrolysis and desalination cell \\
MEDCC & Microbial electrolysis desalination and chemical- \\
MES & production cell \\
MFC & Microbial electrosynthesis \\
MPR & Microbial fuel cell \\
MRCC & Methane production rate \\
MREC & Microbial reverse-electrodialysis chemical- \\
Ni-HFMs & production cell \\
PEM & Microbial reverse-electrodialysis electrolysis cell \\
PRO & Nickel-based hollow-fiber membranes \\
RED & Proton exchange membrane \\
SMDC & Pressure retarded osmosis \\
SMDDC & Reverse electrodialysis \\
SMEBR & Submersible microbial desalination cell \\
SMEC & Submerged microbial desalination-denitrification cell \\
SMFC & Submerged membrane electro-bioreactor \\
UABE & Submersible microbial electrolysis cell \\
UASB & Submersible microbial fuel cell \\
VFA & Up-flow anaerobic bioelectrochemical reactor \\
& Volatile fatty acid \\
\hline
\end{tabular}

\section{Introduction}

One of the biggest global challenges that needs to be addressed is to meet the growing energy demands. Due to the greenhouse gas (GHG) emissions dominantly from the usage of fossil fuels during past centuries, the global temperature has risen unfavorably. In the year 2015, the Paris Agreement set the target to maintain the global average surface temperature below 2 ${ }^{\circ} \mathrm{C}$ with reference to the pre-industrial period (Schleussner et al., 2016) This "safe" level requires to retain over $30 \%, 50 \%$ and $80 \%$ of oil, gas, and coal reserves, respectively, unused before 2050 (McGlade and Ekins, 2015). Therefore, developing renewable and eco-friendly alternatives to fossil fuels is essential (Kadier et al., 2016a).

Hydrogen $\left(\mathrm{H}_{2}\right)$ is considered as a clean and sustainable energy carrier, and has a net calorific value of $119.9 \mathrm{~kJ} / \mathrm{g}$ which is much higher than those of the other fuels like coal $(29.0 \mathrm{~kJ} / \mathrm{g})$, petroleum $(43.4 \mathrm{~kJ} / \mathrm{g})$, ethanol $(26.7$ $\mathrm{kJ} / \mathrm{g}$ ), etc. (Bartels et al., 2010; Njenga et al., 2014). Moreover, during ignition, $\mathrm{H}_{2}$ generates only water which is not harmful to the environment. The potential applications of $\mathrm{H}_{2}$ as future energy are tremendous but still challenging. One of the major issues is the low content of $\mathrm{H}_{2}$ in nature but the demand will be billions of tons per year to build a full hydrogen economy (Turner, 2004).

Today, $\mathrm{H}_{2}$ is mainly produced from unsustainable natural gas and coal (Abdeshahian et al., 2014; Zhen et al., 2017). Other sources include thermolysis or electrolysis of biomass and water (Turner, 2004). These resources are renewable, but require high energy due to the high temperature or usage of electricity (Kadier et al., 2016a). Therefore, biological $\mathrm{H}_{2}$ production from renewable sources, which requires lower energy inputs, offers great potentials to meet future demands (Azman et al. 2016). To date, the most promising biological process for $\mathrm{H}_{2}$ production is dark fermentation (Khanna and Das, 2013). This process can be catalyzed, either by pure or mixed microbial culture (Rittmann and Herwig, 2012), and the substrate can be either pure carbohydrate or organics from diverse wastes (Ren et al., 2011). Furthermore, the specific and volumetric $\mathrm{H}_{2}$ production rate (HPR) can reach over $40 \mathrm{mmolH}_{2} / \mathrm{g} / \mathrm{h}$ and $40 \mathrm{LH}_{2} / \mathrm{L} / \mathrm{d}$, respectively (Kumar and Das, 2001; Rittmann and Herwig, 2012). However, this process has some bottlenecks that restrict the upper boundary of $\mathrm{H}_{2}$ yield. In this process, the yield is relatively low $(<4 \mathrm{~mol} / \mathrm{mol}$ of glucose) and the obtained $\mathrm{H}_{2}$ gas is always mixed with the other anaerobic digestion $(\mathrm{AD})$ gas (e.g., $\mathrm{CO}_{2}$ ), necessitating further purification. These factors increase the overall cost of dark fermentation and thus, limit its industrial applications (Venkata Mohan et al., 2008; Mohanakrishna et al. 2010).

In the past decade, a novel bio-technique named microbial electrolysis cells (MECs) were developed for sustainably producing $\mathrm{H}_{2}$ from wastes (Liu et al., 2005; Rozendal et al., 2006). It could use a wide range of biologically degradable organics as the source of electron (Kadier et al., 
2014; Varanasi et al., 2019). In principle, MECs could overcome the fermentative barrier observed in the fermentation-based processes and exhibit a high theoretical yield of $\mathrm{H}_{2}$ (Kadier et al., 2016a). Moreover, MECs show advantages in terms of vast substrate diversity and low energy input, compared to the other $\mathrm{H}_{2}$ production routes (Kadier et al., 2014). The future of MECs is promising but many issues need to be addressed before their commercialization. System optimization need to be conducted to increase the rate and reduce the cost. Moreover, due to the high modularity of the MEC system (anode, cathode, reactor structure, etc.), integrating with other existing techniques could also bring additional benefits beside the value of $\mathrm{H}_{2}$, which could potentially improve the economic feasibility of MECs and facilitate their commercialization. In this review, we briefly introduce the status quo of knowledge and discuss the pros and cons of MECs. Subsequently, the focus is placed on addressing the potentials of integrating MECs with other existing technologies for fuels and chemicals production.

\section{Fundamentals of microbial electrolysis cells}

The first study on MECs was published by Liu et al. (2005). Since then, exponentially growing numbers of papers were published (Kadier et al., 2016b; $\mathrm{Lu}$ and Ren, 2016). Basically, the exoelectrogens (i.e., the bacteria which can transfer electrons through extracellular mechanism) in MECs use anode as an electron sink to oxidize organics and produce protons and electrons. The protons diffuse via a proton exchange membrane (PEM) to cathode and are reduced by the electrons transferred via the external electric circuit to produce $\mathrm{H}_{2}$. The MEC system cannot work spontaneously due to the thermodynamic barrier and additional energy is required to drive the reduction reaction (Kadier et al., 2015; Kumar et al., 2017). A typical schematic representation of MECs is shown as Figure 1.

In theory, any carbon compounds that can be digested by the exoelectrogens, can be used in anode of MECs. This has led to a large variety of organics sources studied in MECs, ranging from defined pure chemicals to mixture of real wastewaters (Kadier et al., 2014; Escapa et al., 2016). With different carbon sources, the anode potential can range from $0.2-0.5 \mathrm{~V}$. The typical values of some commonly used carbon sources are shown in left side of Figure 1. The half-reaction at the cathode is the reduction of protons to $\mathrm{H}_{2}$ gas. Based on the Nernst equations, the cathode potential will be affected by the concentration of free protons (i.e., $\mathrm{pH}$ of electrolyte), temperature, and partial pressure of $\mathrm{H}_{2}$. As presented in the right side of Figure 1, the cathode potential decreases with increases in temperature, $\mathrm{pH}$ value, and partial pressure of $\mathrm{H}_{2}$. With respect to influence on cathode potential, $\mathrm{pH}$ is the most critical parameter (Rozendal et al., 2006).

The energy input is essential for MECs because of the thermodynamic limitations (Liu et al., 2005; Call and Logan, 2008). Under standard conditions ( $\mathrm{pH}$ of $7, \mathrm{H}_{2}$ partial pressure $\left(\mathrm{pH}_{2}\right)$ of $1 \mathrm{bar}$, and temperature of $25^{\circ} \mathrm{C}$ ), the cathode potential for $\mathrm{H}_{2}$ evolution reaction is about $-0.41 \mathrm{~V}$ (Rozendal, 2006) which is more negative than the anode potentials using most of the carbon sources listed in Figure 1. Theoretically, it should be possible to make the reaction happen spontaneously with glucose as substrate, but glucose in that case has to be fully oxidized to $\mathrm{CO}_{2}$ which does not happen in anaerobic fermentation (Wünschiers and Lindblad, 2002). Another approach to reduce or remove the energy requirement of MECs is to increase the cathode potential by changing the $\mathrm{pH}$ or $\mathrm{pH}_{2}$. This appears feasible since the cathode potential would be high enough if the cathodic electrolyte $\mathrm{pH}$ could be reduced to lower than 5 or maintain the $\mathrm{pH}_{2}$ at lower than 0.001 bar (see Fig。 1). However, maintaining a low $\mathrm{pH}$ in cathode would block the proton migration through the membrane (Rozendal et al., 2006), subsequently resulting in decreased $\mathrm{pH}$ in anode which is harmful to the microorganisms. On the other hand, maintaining an extremely low $\mathrm{pH}_{2}$ is impractical during the operations.

\section{Advantages and disadvantages of MEC technology}

Compared with other $\mathrm{H}_{2}$ producing techniques, one of the advantages of MECs is mild operating conditions. In principle, only $0.11 \mathrm{~V}$ input is needed to drive the $\mathrm{H}_{2}$ production from acetate (Liu et al., 2005; Kadier et al., 2016a), and this is less than $10 \%$ of the typical power (typically 1.23 $2.0 \mathrm{~V}$ ) required for water electrolysis (Kadier et al., 2015). Thus, the energy cost of $\mathrm{H}_{2}$ production in MEC is about $1-3 \mathrm{kWh} / \mathrm{m}^{3}$ (Call and Logan, 2008), while the conventional industrial electrolysers would cost up to 4.5-5.0 $\mathrm{kWh} / \mathrm{m}^{3}$ (Wang et al., 2015).

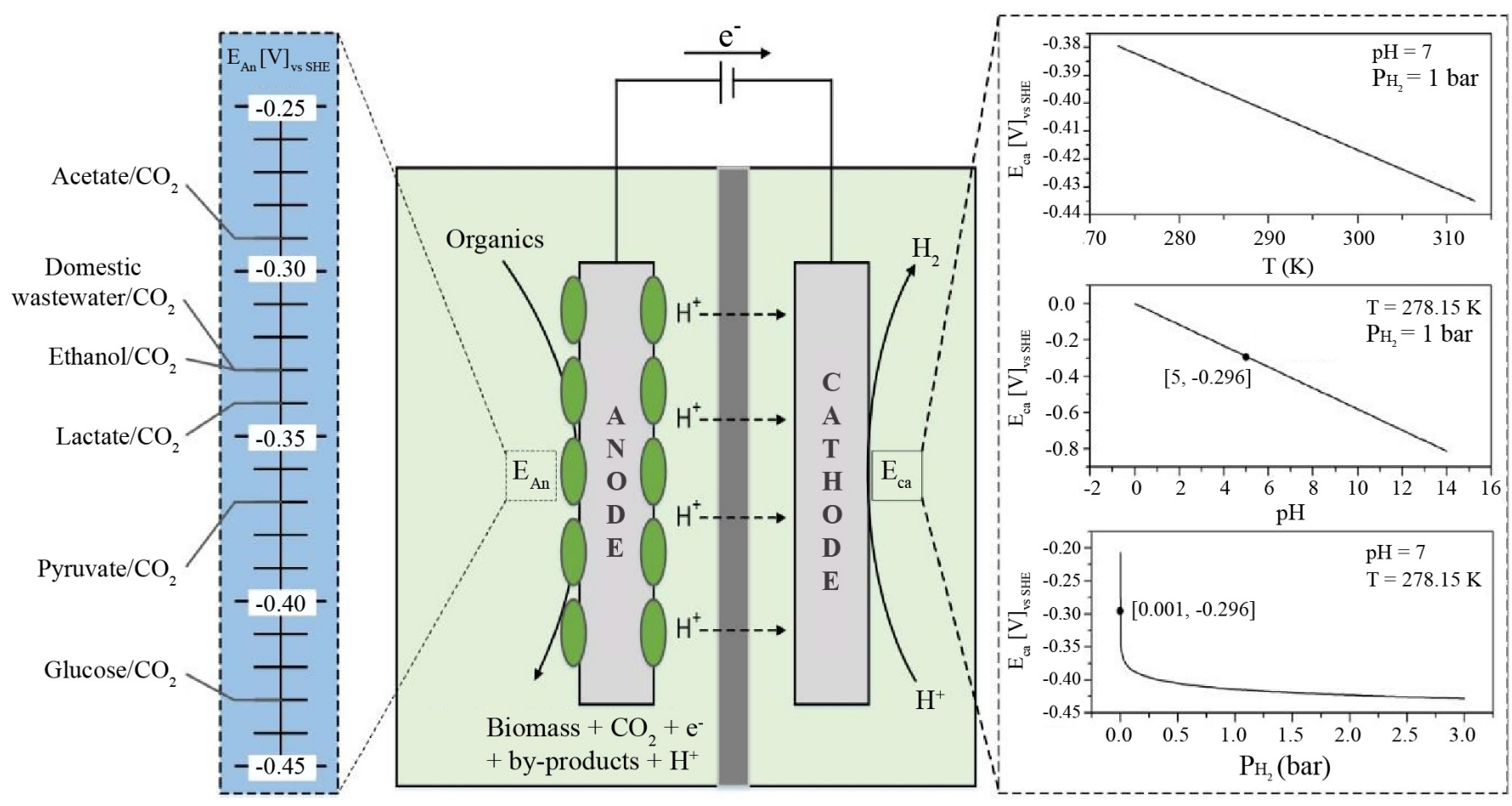

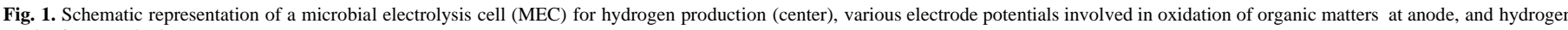
production at cathode. 
In addition to the cost, the yield of $\mathrm{H}_{2}$ is much higher in the MEC process, compared with the fermentation-based processes (Kadier et al., 2016a). Due to the energy barrier discussed above, the stoichiometric yield of $\mathrm{H}_{2}$ is the dark fermentation process is only $4 \mathrm{~mol} \mathrm{H}_{2} / \mathrm{mol}_{\text {glucose }}$ (Venkata Mohan et al., 2007 and 2012), and the typical values reported in real studies are 2.5-3 $\mathrm{mol} \mathrm{H} / \mathrm{mol}_{\text {glucose }}$ (Ren et al., 2011). Many by-products (acetate, butyrate, etc.) are also produced during this process and their conversion into $\mathrm{H}_{2}$ gas is not thermodynamically feasible. Generation of these by-products during dark fermentation also indicates the incomplete degradation of organics during this process. However, if those substances (e.g., acetate, butyrate) can be completely oxidized, the $\mathrm{H}_{2}$ yield could then be dramatically improved (Kadier et al., 2014). Stoichiometrically, this would add up $4 \mathrm{~mol}$ $\mathrm{H}_{2} / \mathrm{mol}_{\text {acetate }}$ and could bring up the total yield of $\mathrm{H}_{2}$ from glucose close to its theoretical limit of $12 \mathrm{~mol} \mathrm{H}_{2} / \mathrm{mol}_{\text {glucose }}$. Moreover, $\mathrm{H}_{2}$ production in dark fermentation is significantly affected by $\mathrm{pH}_{2}$ and would become thermodynamically unfavorable if $\mathrm{H}_{2}$ is highly accumulated in the gas phase (Khanna and Das, 2013). On the contrary, the effect of partial pressure on cathode potential in MEC is found to be minor and this factor will not alter the performance of MEC system. Furthermore, MECs are superior in terms of the purity of $\mathrm{H}_{2}$ as well. Due to the spatial separation of organic degradation and $\mathrm{H}_{2}$ production in MECs, it is likely to have other gases such as carbon dioxide and other fermentation gases in minor proportions (Sravan et al., 2019). The purity of $\mathrm{H}_{2}$ is essential for its various downstream applications, for example, it has to be sulfur-free to be used in proton exchange membrane fuel cell systems.

Overall, MECs present a bright future for superior $\mathrm{H}_{2}$ production and yield, with high purity at a low energy cost. However, its commercialization is strongly limited by HPR. More specifically, the HPR in MECs at laboratory scale could only reach about $3 \mathrm{~m}^{3} \mathrm{H}_{2} / \mathrm{m}^{3}$ of reactor volume/d (Call and Logan, 2008; Escapa et al., 2016; Li et al., 2018). The HPR could reportedly even deteriorate while scaling up the process (Rozendal et al., 2008; Cusick et al., 2012; Heidrich et al., 2014). The lower hydrogen production and lower current density recorded with pilot reactors, compared to the laboratory reactors were due to several differences between these systems. These differences can be listed as reactor geometry, electrode materials, inclusion of glass fiber separators, possible connection resistances, and microbiological factors resulting in relatively slow startup of the reactor. Methane production is also one of the possibilities for the lower HPR at pilot scale (Cusick et al., 2012). Maximum volumetric HPR in small-scale (volume $<100 \mathrm{~mL}$ ) MECs could reach $50 \mathrm{~m}^{3} \mathrm{H}_{2} / \mathrm{m}^{3} / \mathrm{d}$ (Lu and Ren, 2016). Therefore, MECs seem to be more suitable as decentralized systems for $\mathrm{H}_{2}$ production at domestic sites. Integrating MECs with other existing techniques to generate extra benefits could also potentially be an efficient approach to improve their industrial feasibility in the future.

\section{MEC integration with other technologies}

\subsection{MEC-microbial fuel cell (MFC) coupled system}

Microbial fuel cells (MFCs) are systems used to produce power by degrading various wastes (Deval et al., 2017). In recent studies, MFCs were proposed as renewable power sources to operate MEC. The concept was demonstrated using a novel system integrating a single chambered MFC and a dual chambered MEC (MEC-MFC-coupled system) and was successfully used for $\mathrm{H}_{2}$ production without external power supplementation. Peak systemic $\mathrm{H}_{2}$ yield of $1.21 \mathrm{~mol} \mathrm{H}_{2} / \mathrm{mol}_{\text {acetate }}$ and $\mathrm{HPR}$ of $14.9 \pm 0.4 \mathrm{~mL} / \mathrm{L} / \mathrm{d}$ were achieved using acetate as substrate with the developed MEC-MFC-coupled system (Fig. 2) (Sun et al., 2008). Later, a bio-photo-electrochemical cell (BPEC) design was proposed by Wan et al. (2015), also comprising MFC and MEC. Illumination of BPEC photocathode with the visible light led to $\mathrm{H}_{2}$ production, and the MFC supplied the voltage for electrolysis. The process produced $\mathrm{H}_{2}$ at the rate of $1.35 \pm 0.15 \mathrm{~mL} / \mathrm{h}$ and registered a current density of $0.68 \mathrm{~A} / \mathrm{m}^{2}$ (Table 1) (Wan et al., 2015).

Apart from $\mathrm{H}_{2}$ generation, MFCs can be used to power virtually any MEC systems (Wan et al., 2015). Accordingly, a group of researchers proposed the use of MFC to supply power to an MEC used to convert carbon dioxide to formic acid and obtained a significant production rate $(21.0 \pm 0.2 \mathrm{mg} / \mathrm{L} / \mathrm{h})$ (Zhao et al., 2012). The energy generated from the wastewater treatment or acetate oxidation in MFC can also be integrated with MEC to drive $\mathrm{H}_{2}$ production or $\mathrm{CO}_{2}$ reduction to value-added products (termed as microbial electrosynthesis (MES) (Mohanakrishna et al., 2016 and 2018; Roy et al. 2016). As the integration is possible in-situ, energy losses can be minimized significantly. However, as MEC requires a constant reduction potential, therefore, more stable MFC systems need to be developed for a balanced integration.

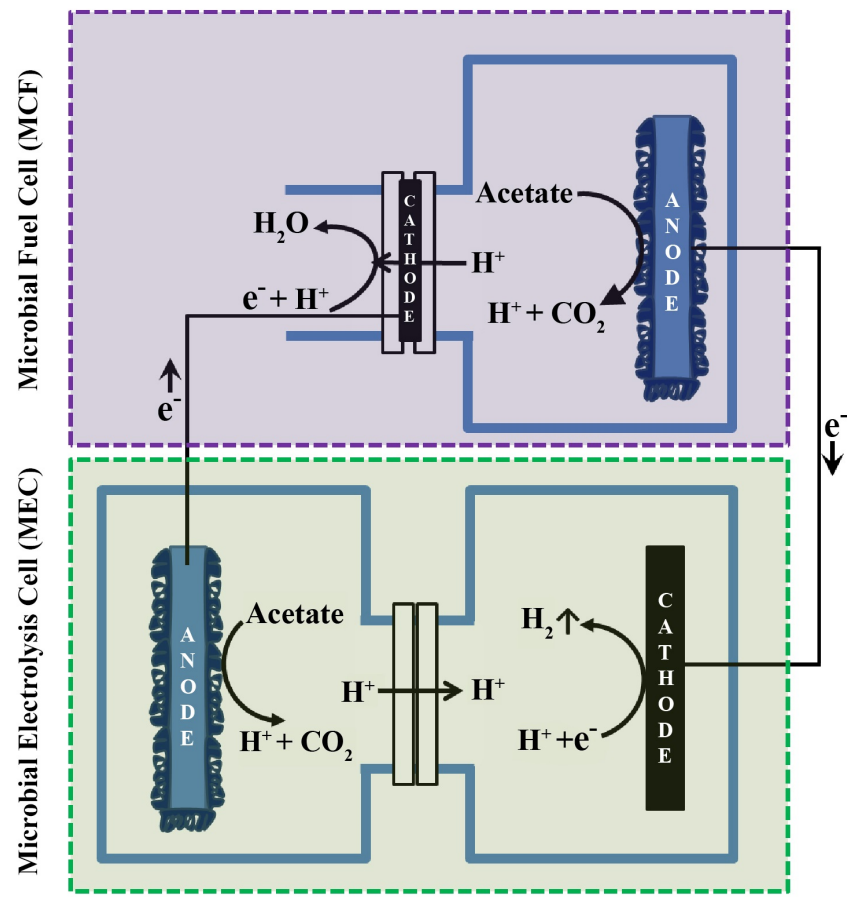

Fig. 2. Working principles of the microbial electrolysis cell coupled with microbial fuel cel (MEC-MFC) system. Redrawn from Sun et al. (2008). With permission from ACS. Copyright@ 2008

\subsection{Submersible microbial electrolysis cell (SMEC)}

Submersible microbial electrolysis cells (SMECs) were designed in an effort to remove the external power supply required for the operation of a typical MEC. These cells can be easily fixed into existing anaerobic digesters, where two jointed chambers are inserted functioning as two cathode chambers. There is no separate anode chamber and one of the cathode chambers is used to produce electricity, while the other chamber is designed to produce $\mathrm{H}_{2}$. In an innovative study, Zhang and Angelidaki (2012) introduced a self-powered SMEC to produce $\mathrm{H}_{2}$ in-situ from anaerobic digesters. The highest systemic yield of $\mathrm{H}_{2}$ achieved was 1.43 mol $\mathrm{H}_{2} / \mathrm{mol}_{\text {acetate }}$ with $20 \mathrm{mM}$ acetate, where the maximum current density and coulombic efficiency were registered at $1778 \mathrm{~mA} / \mathrm{m}^{2}$ and $28 \%$, respectively (Zhang and Angelidaki, 2012) (Table 1). This same group of researchers also developed a similar technology called submersible MFC (SMFC) as a biosensor to monitor microbial activity and biological oxygen demand (BOD) in groundwater (Zhang and Angelidaki, 2011). A mature anodic biofilm was used in the MFC to measure BOD, wherein the current production was correlated with BOD of the water sample. Since, type of the inoculum and its concentration influences the bacterial cell adhesion to the electrode surface, a fresh anode was used to evaluate the microbial activity (Zhang and Angelidaki, 2011). In another study, ammonia inhibition in AD was overcome by a novel hybrid system consisting of a submersible microbial desalination cell (SMDC) and a continuous stirred tank reactor (CSTR). This integration not only resulted in in-situ ammonia recovery and electricity production but also led to $112 \%$ additional biogas production (Zhang and Angelidaki, 2015). Another variation of submersible cells was also proposed later, called submerged microbial desalination-denitrification cell (SMDDC). It was used for in-situ removal of nitrate from groundwater and produced electric energy. Additionally, added value was created in 
Table 1.

Various integration processes of microbial electrolysis cells (MEC) with different technologies for energy generation.

\begin{tabular}{|c|c|c|c|c|c|c|c|c|c|c|}
\hline \multirow{2}{*}{$\begin{array}{l}\text { S. } \\
\text { No }\end{array}$} & \multirow{2}{*}{$\begin{array}{l}\text { Integration } \\
\text { type }\end{array}$} & \multirow{2}{*}{ Type of electrode } & \multirow{2}{*}{$\begin{array}{l}\text { Applied energy } \\
\text { (Voltage or } \\
\text { current) }\end{array}$} & \multicolumn{2}{|c|}{ Operational conditions } & \multirow{2}{*}{ Hydrogen } & \multirow{2}{*}{$\begin{array}{l}\text { Current or power } \\
\text { density }\end{array}$} & \multirow{2}{*}{$\begin{array}{c}\text { Coulombic } \\
\text { efficiency }(\mathrm{CE}, \\
\%)\end{array}$} & \multirow{2}{*}{ Remarks } & \multirow{2}{*}{ Reference } \\
\hline & & & & Electrolyte & Type & & & & & \\
\hline \multirow{2}{*}{1} & \multirow{2}{*}{$\begin{array}{l}\text { MEC with } \\
\text { microbial fuel } \\
\text { cell (MFC) }\end{array}$} & \multirow{2}{*}{$\begin{array}{l}\text { Anode: Carbon brush } \\
\text { Cathode: Silicon } \\
\text { nanowires (photo } \\
\text { cathode) }\end{array}$} & \multirow{2}{*}{ N/A } & \multirow{2}{*}{$\begin{array}{l}\text { Growth } \\
\text { media }\end{array}$} & \multirow{2}{*}{$\begin{array}{l}\text { Single } \\
\text { chamber }\end{array}$} & $1.35 \mathrm{~mL} / \mathrm{h}$ & $\begin{array}{c}0.68 \mathrm{~A} / \mathrm{m}^{2} \text { (Light } \\
\text { conditions) }\end{array}$ & \multirow{2}{*}{ N/A } & \multirow{2}{*}{$\begin{array}{l}\text { Solar assisted } \\
\text { MEC }\end{array}$} & \multirow{2}{*}{$\begin{array}{l}\text { Wan et al. } \\
\text { (2015) }\end{array}$} \\
\hline & & & & & & $0.72 \mathrm{~mL} / \mathrm{h}$ & $\begin{array}{l}0.52 \mathrm{~A} / \mathrm{m}^{2} \text { (Dark } \\
\text { conditions) }\end{array}$ & & & \\
\hline \multirow{6}{*}{2} & \multirow{6}{*}{$\begin{array}{l}\text { MEC with } \\
\text { dye-sensitized } \\
\text { solar cell }\end{array}$} & $\begin{array}{l}\text { Anode: Carbon felt } \\
\text { (CF) }\end{array}$ & \multirow{6}{*}{$0.7 \mathrm{~V}$} & \multirow{6}{*}{$\begin{array}{l}\text { Growth } \\
\text { media }\end{array}$} & \multirow{6}{*}{ H-type } & & & \multirow{6}{*}{ N/A } & \multirow{6}{*}{-} & \multirow{6}{*}{$\begin{array}{l}\text { Chae et al. } \\
\text { (2009) }\end{array}$} \\
\hline & & $\begin{array}{l}\text { Cathode: } \\
\text { Plain graphite }\end{array}$ & & & & $536 \mu \mathrm{mol}$ & N/A & & & \\
\hline & & $\begin{array}{l}\text { Platinum (Pt.)-loaded } \\
\text { graphite }\end{array}$ & & & & $586 \mu \mathrm{mol}$ & N/A & & & \\
\hline & & Plain CF & & & & $599 \mu \mathrm{mol}$ & N/A & & & \\
\hline & & Pt.-loaded CF & & & & $627 \mu \mathrm{mol}$ & N/A & & & \\
\hline & & $\begin{array}{l}\text { Carbon nanopowder } \\
(\mathrm{CNP}) \text {-coated } \mathrm{CF}\end{array}$ & & & & $600 \mu \mathrm{mol}$ & $\begin{array}{l}1.2 \mathrm{~mA} \text { (Light } \\
\text { conditions) }\end{array}$ & & & \\
\hline 3 & MEC with MFC & $\begin{array}{l}\text { Anode: Carbon paper } \\
\text { Cathode: Pt. coated } \\
\text { cathode paper }\end{array}$ & $\begin{array}{l}0.8 \mathrm{~V} \\
10 \Omega\end{array}$ & $\begin{array}{l}\text { Growth } \\
\text { media }\end{array}$ & $\begin{array}{l}\text { Double } \\
\text { chamber }\end{array}$ & $14.9 \mathrm{~mL} / \mathrm{L} . \mathrm{d}$ & $0.25 \mathrm{~mA}$ & $\begin{array}{l}\text { MEC: } 64 \% \\
\text { MFC-MEC: } \\
33 \%\end{array}$ & - & $\begin{array}{l}\text { Sun et al. } \\
\text { (2008) }\end{array}$ \\
\hline \multirow{6}{*}{4} & \multirow{6}{*}{$\begin{array}{l}\text { MEC with } \\
\text { hydrogen } \\
\text { bioreactor } \\
\text { (HBR) }\end{array}$} & & Control & & & $0.33 \mathrm{mmol} / \mathrm{h}$ & & & & \\
\hline & & & $0.2 \mathrm{~V}$ & & & $0.35 \mathrm{mmol} / \mathrm{h}$ & & & HBR+MEC & \\
\hline & & Anode: Graphite plate & $0.5 \mathrm{~V}$ & -HBR effluent & Single & $0.42 \mathrm{mmol} / \mathrm{h}$ & $\mathrm{N} / \mathrm{A}$ & $\mathrm{N} / \mathrm{A}$ & led to the best & Babu et al. \\
\hline & & $\begin{array}{l}\text { Camoae: Urapnite } \\
\text { plate }\end{array}$ & $0.6 \mathrm{~V}$ & 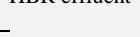 & chamber & $0.53 \mathrm{mmol} / \mathrm{h}$ & 18 & 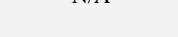 & performance & (2013) \\
\hline & & & $0.8 \mathrm{~V}$ & & & $0.46 \mathrm{mmol} / \mathrm{h}$ & & & & \\
\hline & & & $1.0 \mathrm{~V}$ & & & $0.50 \mathrm{mmol} / \mathrm{h}$ & & & & \\
\hline & MEC with & Anode: Carbon brush & $0.6 \mathrm{~V}$ & & & $18.4 \mathrm{~mL}$ & $2.7 \mathrm{~mA}$ & $36.1 \%$ & & \\
\hline 5 & forward osmosis & Cathode: Pt. coated & $0.8 \mathrm{~V}$ & $\begin{array}{l}\text { Synthetıc } \\
\text { wastewater }\end{array}$ & $\begin{array}{l}\text { Double } \\
\text { chamber }\end{array}$ & $32.8 \mathrm{~mL}$ & $4.5 \mathrm{~mA}$ & $57.5 \%$ & - & $\begin{array}{l}\text { Yuan et al. } \\
\text { (2015) }\end{array}$ \\
\hline & & carbon cloth & $1.0 \mathrm{~V}$ & & & $40.8 \mathrm{~mL}$ & $6.6 \mathrm{~mA}$ & $58.3 \%$ & & \\
\hline 6 & MEC with FO & $\begin{array}{l}\text { Anode: CF stuck on } \\
\text { perforated stainless- } \\
\text { steel plate using silver } \\
\text { paste }\end{array}$ & $0.7 \mathrm{~V}$ & $\begin{array}{c}\text { Synthetic } \\
\text { wastewater }\end{array}$ & $\begin{array}{l}\text { Double } \\
\text { chamber }\end{array}$ & $\begin{array}{c}12.5 \pm 1.84 \times 10^{-3} \mathrm{~m}^{3} \\
\mathrm{H}_{2} / \mathrm{m}^{3} / \mathrm{d}\end{array}$ & $3.34 \pm 0.24 \mathrm{~A} / \mathrm{m}^{2}$ & $13.1 \pm 2.65 \%$ & - & $\begin{array}{l}\text { Lee et al. } \\
\text { (2015) }\end{array}$ \\
\hline & & $\begin{array}{l}\text { Cathode: Perforated } \\
\text { titanium plate }\end{array}$ & & & & & & & & \\
\hline 7 & $\begin{array}{l}\text { MEC with } \\
\text { anaerobic }\end{array}$ & Anode: CF & $0.4 \mathrm{~V}$ & $\begin{array}{l}\text { Anaerobic } \\
\text { digestion }\end{array}$ & Single & $0 \mathrm{~mL}$ & $1.3 \mathrm{~mA}$ & N/A & $\begin{array}{c}\mathrm{AD}+\mathrm{MEC} \\
\text { were }\end{array}$ & Bo et al. \\
\hline 1 & $\begin{array}{l}\text { anaerobic } \\
\text { digester }\end{array}$ & $\begin{array}{l}\text { Cathode: Stainless } \\
\text { steel }\end{array}$ & $1.0 \mathrm{~V}$ & $\begin{array}{l}\text { digestion } \\
\text { effluent }\end{array}$ & chamber & $7 \mathrm{~mL}$ & $25 \mathrm{~mA}$ & N/A & $\begin{array}{l}\text { combined to } \\
\text { upgrade } \mathrm{CH}_{4}\end{array}$ & (2014) \\
\hline 8 & $\begin{array}{l}\text { MEC with } \\
\text { anaerobic } \\
\text { digester }\end{array}$ & $\begin{array}{l}\text { Anode: Carbon brush } \\
\text { Cathode: Stainless } \\
\text { steel mesh }\end{array}$ & $0.8 \mathrm{~V}$ & $\begin{array}{c}\text { Sludge } \\
\text { fermentation } \\
\text { liquid }\end{array}$ & $\begin{array}{l}\text { Double } \\
\text { chamber }\end{array}$ & NA & $\begin{array}{l}9.6 \mathrm{~mA} \text { (average } \\
\text { for } 2 \text { reactors) }\end{array}$ & NA & $\begin{array}{c}\mathrm{AD}+\mathrm{MEC} \\
\text { were } \\
\text { combined to } \\
\text { upgrade } \mathrm{CH}_{4}\end{array}$ & $\begin{array}{l}\text { Cai et al. } \\
\text { (2016) }\end{array}$ \\
\hline 9 & $\begin{array}{l}\text { MEC with } \\
\text { anaerobic } \\
\text { digester }\end{array}$ & $\begin{array}{l}\text { Anode: } \text { Carbon brush } \\
\text { Cathode: } \mathrm{Ti} / \mathrm{RuO}_{2}\end{array}$ & $0.0-0.8 \mathrm{~V}$ & $\begin{array}{c}\text { Food waste }+ \\
\text { sewage } \\
\text { sludge in } \\
\text { varying } \\
\text { ratios }\end{array}$ & $\begin{array}{l}\text { Single } \\
\text { chamber }\end{array}$ & $\begin{array}{l}\text { Maximum } \mathrm{CH}_{4} \text { at } 0.4 \mathrm{~V} \\
(2.8 \text { folds increase })\end{array}$ & $\begin{array}{l}\text { Steady increase in } \\
\text { current with } \\
\text { applied voltage }\end{array}$ & NA & $\begin{array}{c}\mathrm{AD}+\mathrm{MEC} \\
\text { were } \\
\text { combined to } \\
\text { upgrade } \mathrm{CH}_{4}\end{array}$ & $\begin{array}{l}\text { Zhi et al. } \\
\text { (2019) }\end{array}$ \\
\hline 10 & $\begin{array}{l}\text { MEC with } \\
\text { anaerobic } \\
\text { digester }\end{array}$ & $\begin{array}{l}\text { Anode: } \mathrm{CF} \\
\text { Cathode: } \text { stainless- } \\
\text { steel mesh }\end{array}$ & $0 \mathrm{mV}$ & $\begin{array}{l}\text { Raw pig } \\
\text { slurry }\end{array}$ & $\begin{array}{l}\text { Double } \\
\text { chamber }\end{array}$ & $\begin{array}{c}0.42 \pm 0.05 \mathrm{~m}^{3} \mathrm{CH}_{4} / \mathrm{m}^{3} / \mathrm{d} \\
(55 \% \text { increase) }\end{array}$ & $\begin{array}{c}\text { Maximum current } \\
\text { density: } 2.01 \pm 0.63 \\
\mathrm{~A} / \mathrm{m}^{2}\end{array}$ & NA & $\begin{array}{l}\text { AD-MEC } \\
\text { loop system } \\
\text { was used }\end{array}$ & $\begin{array}{l}\text { Cerrillo et } \\
\text { al. (2016) }\end{array}$ \\
\hline 11 & $\begin{array}{l}\text { MEC with } \\
\text { simultaneous } \\
\text { desalination }\end{array}$ & $\begin{array}{l}\text { Anode: Carbon cloth } \\
\text { Cathode: Pt. coated } \\
\text { carbon cloth }\end{array}$ & $0.55 \mathrm{~V}$ & $\begin{array}{l}\text { Phosphate } \\
\text { buffer } \\
\text { solution }\end{array}$ & $\begin{array}{l}\text { MDC } \\
\text { (Triple } \\
\text { chamber) }\end{array}$ & $\begin{array}{c}6.5 \mathrm{ml}(5 \mathrm{~g} / \mathrm{L} \text { salt }) \\
2.7 \mathrm{ml}(20 \mathrm{~g} / \mathrm{L} \text { salt })\end{array}$ & $\begin{array}{l}1.4 \mathrm{~A} / \mathrm{m}^{2} \\
1.2 \mathrm{~A} / \mathrm{m}^{2}\end{array}$ & $\begin{array}{c}48 \%(5 \mathrm{~g} / \mathrm{L} \text { salt }) \\
16 \%(20 \mathrm{~g} / \mathrm{L} \\
\text { salt })\end{array}$ & $\mathrm{MDC}+\mathrm{MEC}$ & $\begin{array}{l}\text { Mehanna } \\
\text { et al. } \\
(2010)\end{array}$ \\
\hline 12 & $\begin{array}{l}\text { Dark fermentor } \\
\text { (DrF)-MEC- } \\
\text { MFC }\end{array}$ & $\begin{array}{l}\text { Anode: Carbon brush } \\
\text { Cathode: Pt. coated } \\
\text { carbon cloth }\end{array}$ & $\begin{array}{l}\text { Power output } \\
\text { of stack MFC } \\
0.33 \text { to } 0.47 \mathrm{~V}\end{array}$ & DrF effluent & $\begin{array}{l}\text { Single } \\
\text { chamber }\end{array}$ & $0.48 \mathrm{~m}^{3} \mathrm{H}_{2} / \mathrm{m}^{3} / \mathrm{d}$ & $52 \mathrm{~A} / \mathrm{m}^{3}$ (MEC) & $57 \%$ (MEC) & $\begin{array}{l}\text { Stack MFC } \\
\text { with forest } \\
\text { organics }\end{array}$ & $\begin{array}{l}\text { Wang et } \\
\text { al. }(2015)\end{array}$ \\
\hline
\end{tabular}

Please cite this article as: Kadier A., Jain P., Lai B., Kalil M.S., Kondaveeti S., Alabbosh K.F.S., Abu-Reesh I.M., Mohanakrishna G. Biorefinery perspectives of microbial electrolysis cells (MECs) for hydrogen and valuable chemicals production through wastewater treatment. Biofuel Research Journal 25 (2020) 1128-1142. DOI: $10.18331 /$ BRJ2020.7.1.5 
Table 1.

continued.

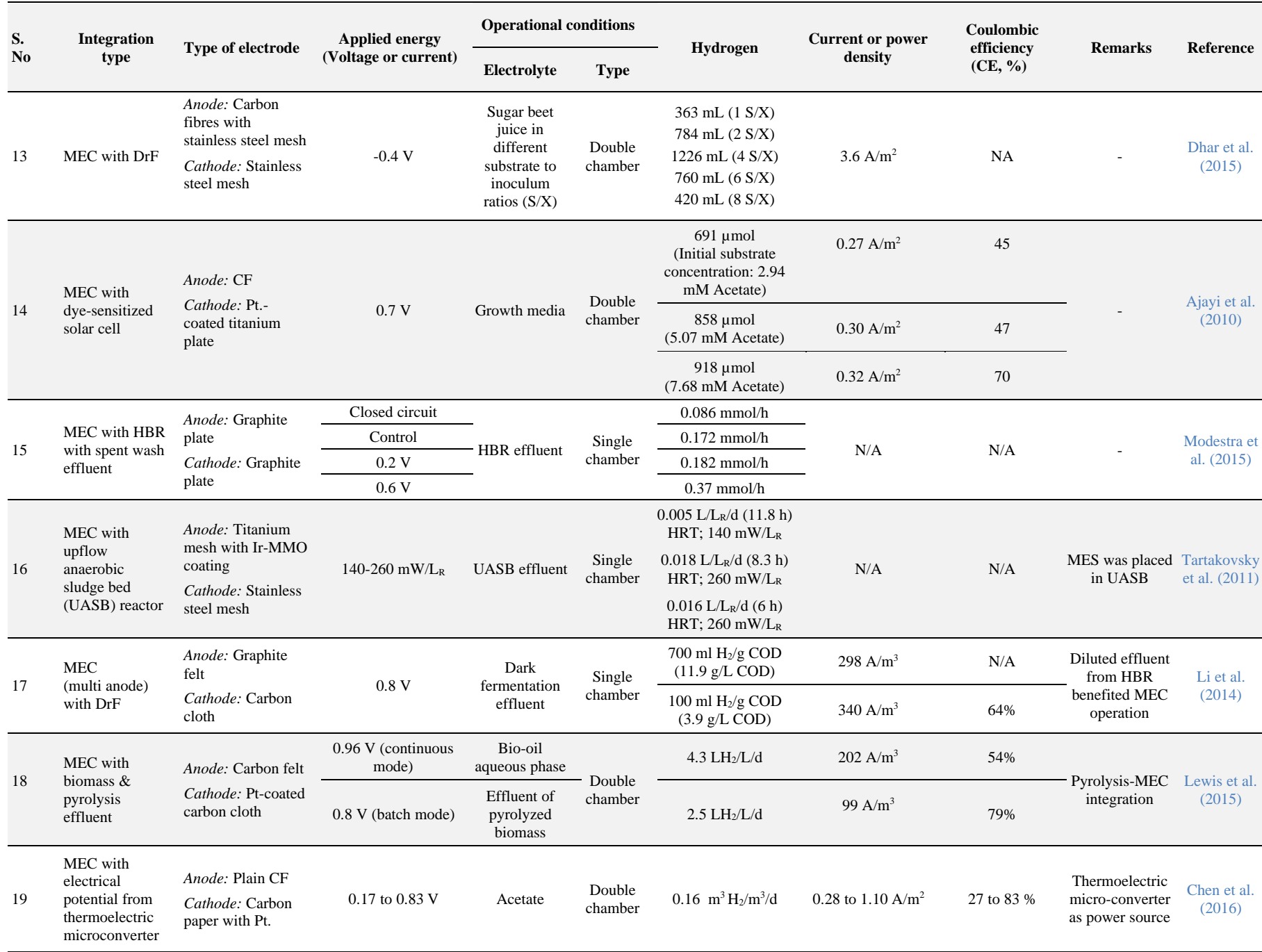

terms of wastewater treatment (Fig. 3a) (Zhang and Angelidaki, 2013). Bioelectricity was produced by the anodic bacterial activity. Both $\mathrm{NO}_{3}{ }^{-}$and $\mathrm{Na}^{+}$ were ion-transported to the anode and cathode by anion (AEM) and cation exchange membranes (CEM), respectively. The effluent from the anode was directed to the cathode, where $\mathrm{NO}_{3}{ }^{-}$was reduced to nitrogen gas by autotrophic denitrification. Subsequently, SMDDC removed $90.5 \%$ of the nitrate from groundwater with wastewater hydraulic retention time (HRT) of $12 \mathrm{~h}$ (Zhang and Angelidaki, 2013). Submerged electrolysis cells configuration demonstrated the potentiality of the integration of the MECs with anaerobic digesters and MDCs. The proof of concept studies also proved that submersible configurations could also offer simultaneous economic bioremediation of wastewater and energy recovery.

\subsection{Solar powered $M E C$}

Solar energy is renewable and is freely available all over the world and thus, is considered as a favorable option to meet the world energy demands. Therefore, the energy required to run MECs could also be potentially derived from solar energy in the form of a dye-sensitized solar cell (DSSC). Solar cell-
MEC-coupled system converts solar energy to liquid or gas transportation fuels such as $\mathrm{H}_{2}, \mathrm{CH}_{4}$, and ethanol, which could be subsequently stored for future use (Zhang and Angelidaki, 2014). Chae et al. (2009) successfully generated $\mathrm{H}_{2}$ in a solar powered MEC with $\mathrm{H}_{2}$ conversion efficiency of $82 \%$ from acetate. DSSCs fabricated with a dye-sensitized $\mathrm{TiO}_{2}$-based anode were used to harvest solar energy (Chae et al., 2009). Ajayi et al. (2010) connected four MECs to a single dye (N719) sensitized solar cell ( $\mathrm{V}_{\mathrm{OC}} \approx 0.7$ V) for biohydrogen production (Table 1). Also, as reported by other researchers, $\mathrm{H}_{2}$ production in DSSCs was similar to that obtained from MECs with a conventional power supply (Fig. 3b). The substrate to product (acetate to $\mathrm{H}_{2}$ ) conversion efficiency in the DSSCs ranged from $42-65 \%$ for the four connected MECs. To improvise such systems further, Wan et al. (2015) designed a BPEC powered by a MFC. This BPEC comprised of a photocathode and a microbially-catalyzed anode while the MFC was used as additional voltage supply to overcome cathode overpotentials. The HPR obtained with this novel hybrid system was $1.35 \pm 0.15 \mathrm{~mL} / \mathrm{h}$ (Wan et al. 2015). Thus, in the MEC-DSSC process, the current density is regulated by the light intensity and the performance of anodic microbiological catalys of MEC. Since the voltage demand is not very high (usually about $0.8 \mathrm{~V}$ ) 
a

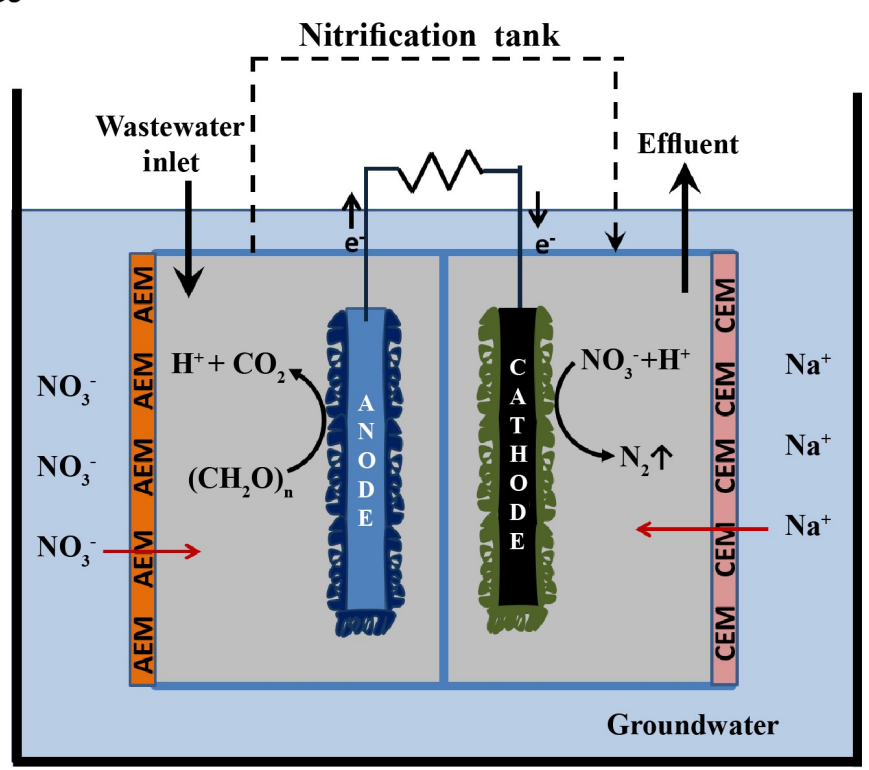

b

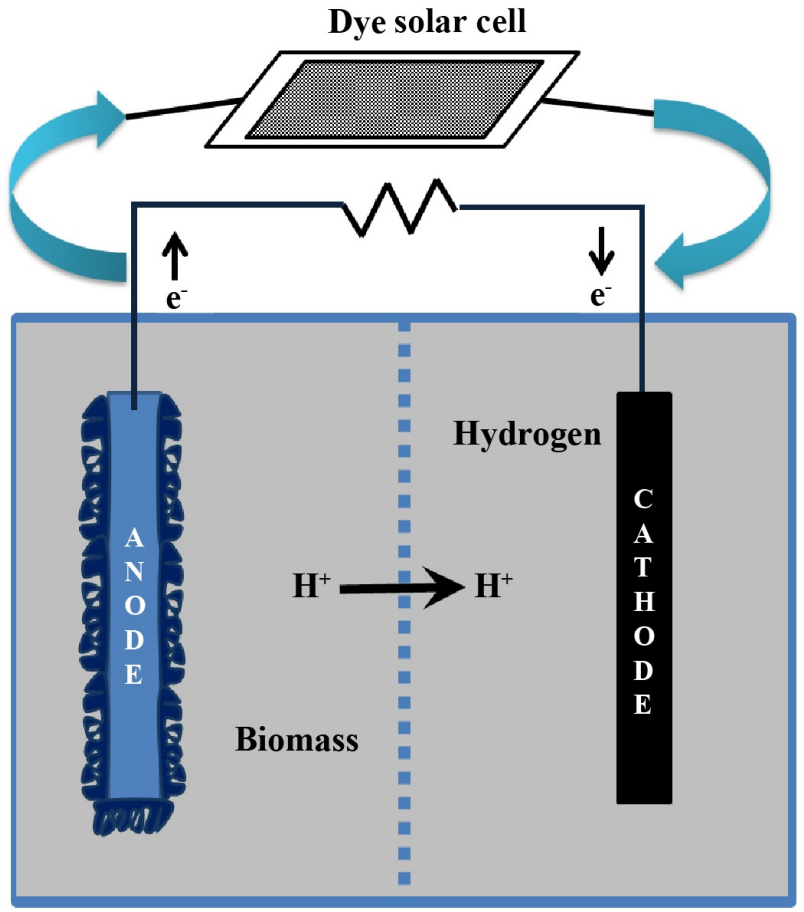

\section{Microbial electrolysis cell (MEC)}

Fig. 3. Schematic representation of (a) the principle to remove nitrate from groundwater using novel submerged microbial desalination-denitrification cell (SMDDC) and (b) the principle to produce hydrogen thorough microbial electrolysis cell integrated with dye sensitized solar cell (MEC-DSSC) system. Redrawn from Ajayi et al. (2010). With permission from RSC. Copyright $\odot 2010$.

and that it can be met with light of moderate intensity, the microbially catalyzed anode becomes the limiting factor for such systems. Fischer et al. (2018) argued that the application of solar powered MECs would be a cheaper way to produce hydrogen than most other comparable processes. Different photocatalytic materials enable the hydrogen evolution reaction. Materials like $\mathrm{TiO}_{2}$ nanorods, $\mathrm{Cu}_{2} \mathrm{O}$, and $\mathrm{Cu}_{2} \mathrm{O} / \mathrm{NiOx}$ composite were evaluated for the effective light supported hydrogen evolution reaction in MECs. However, more research is required to transform the currently available solar powered MECs to commercial hydrogen production platforms (Fischer et al., 2018).

\subsection{Dark fermentation and MFC-MEC coupled system}

Biological $\mathrm{H}_{2}$ production from dissolved organic materials in wastewaters provides an opportunity to utilize this untapped resource via dark fermentation. However, there are many thermodynamic barriers which pose technical challenges to obtain favorable yields through the dark fermentation process (Rozendal et al., 2006). Due to these thermodynamic limitations, several byproducts like acetate and butyrate are formed instead of $\mathrm{H}_{2}$, and external energy needs to be supplied for a thermodynamically feasible reaction (Zhang and Angelidaki, 2012). Dark fermentation of 1 mole of glucose yields a maximum of 4 moles of $\mathrm{H}_{2}$ and 2 moles of acetate (Venkata Mohan et al., 2008 and 2012). Further, acetate can also be converted into $\mathrm{H}_{2}$ gas by biocatalyzed electrolysis. The combination of both processes could achiev a theoretical production of 12 moles $\mathrm{H}_{2} /$ mole $_{\text {glucose }}$ (Clauwaert et al., 2008). In a study, dark fermentation of corn stalk was integrated with an MEC (poised at $0.8 \mathrm{~V}$ ), thereby tripling the rate of $\mathrm{H}_{2}$ production (387.1 $\mathrm{mL} \mathrm{H} / \mathrm{g}$-corn stalk) as compared to the dark fermentation alone (Li et al., 2014). This concept of utilizing unused energy of dark fermentation through MECs was also demonstrated by Rivera et al (2015) using the effluent of dark fermentation as substrate for MEC operation. The effluent containing various volatile fatty acids (VFA) produced $81 \mathrm{~mL} \mathrm{H}_{2} / \mathrm{L} / \mathrm{d}$ with an organic removal rate of $85 \%$ (Rivera et al., 2015). Wang et al. (2015) used a novel approach to extract maximum $\mathrm{H}_{2}$ from cellulose. They connected two MFCs in series to an MEC system to produce $0.43 \mathrm{~V}$ using fermentation effluent as substrate and achieved an HPR of $0.48 \mathrm{~m}^{3} \mathrm{H}_{2} / \mathrm{m}^{3} / \mathrm{d}\left(33.2 \mathrm{mmol} \mathrm{H}_{2} / \mathrm{g}\right.$ chemical oxygen demand-COD) (Table 1). The overall $\mathrm{H}_{2}$ production for the integrated system comprising a dark fermenter, MFC and MEC (in series) resulted in $41 \%$ higher $\mathrm{H}_{2}$ production than the fermentation alone. Thus, without using an external electrical supply, higher $\mathrm{H}_{2}$ yield was achieved using this combined fermentation and MFC-MEC.

\subsection{Integration of pyrolysis-MEC}

Fuel sources produced from the biomass origin by different biological and thermochemical processes are named renewable hydrocarbon biofuels. These fuels are also termed as green-hydrocarbons, bio-hydrocarbons, drop-in biofuels, and sustainable or advanced hydrocarbon biofuels (Fig. 4). Pyrolysis is a process, where thermochemical decomposition of organic materials occurs at high temperatures in the absence of $\mathrm{O}_{2}$ and is used for the production of these bio-hydrocarbons (Borole, 2015). The high $\mathrm{O}_{2}$ content in biomass (> 40\%), lowers the yield of bio-hydrocarbons from them. This problem is often handled by supplying the fuel finishing step with a source of $\mathrm{H}_{2}$. Due to the current unavailability of commercial renewable sources of $\mathrm{H}_{2}$, fossil resources are required for its production, which in turn, impact its sustainability. Alternatively, $\mathrm{H}_{2}$ can be derived from the liquid/aqueous waste streams produced during pyrolysis via microbial electrolysis, thus offering a sustainable source of $\mathrm{H}_{2}$ (Borole, 2015). The blend of organic and aqueous phases generated through pyrolysis is known as bio-oil. The organic content of liquid phase bio-oil includes organic acids, furan aldehydes, phenolic compounds, and sugar derivatives. These organic compounds are reported as potential bioanode substrates for $\mathrm{H}_{2}$ production in MECs. The aqueous stream generated during pyrolysis of switchgrass was used as substrate for $\mathrm{H}_{2}$ production in MEC, reaching an overall energy efficiency of 48-63\% (Lewis et al., 2015; Table 1). Maximum HPR of $4.3 \mathrm{~L} \mathrm{H}_{2} / \mathrm{L}_{\text {anode }} / \mathrm{d}$ (loading of $10 \mathrm{~g}$ $\mathrm{COD} / \mathrm{L}_{\text {anode }} / \mathrm{d}$ ) was recorded through (approx.) complete conversion of acetic acid, propionic acid, levoglucosan, and furfural. Thus, the $\mathrm{H}_{2}$ produced from the integrated process could be utilized to hydrodeoxygenate bio-oil to produce fuel (Lewis et al., 2015). 

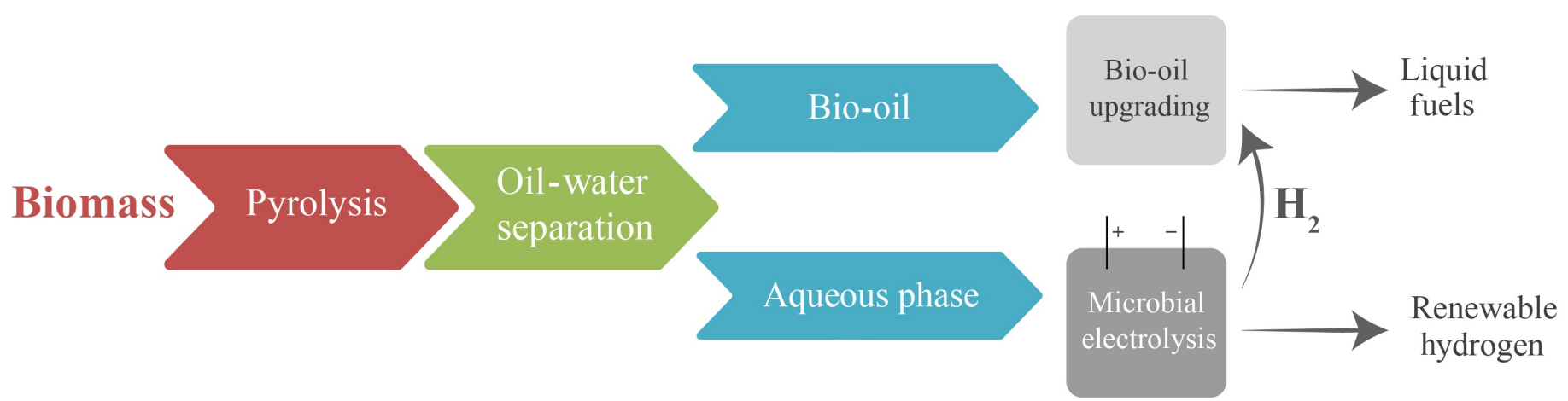

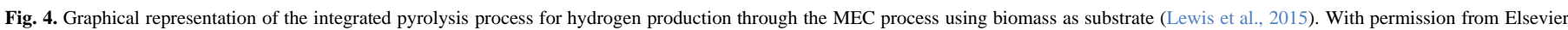
Copyright@ 2015.

\subsection{Microbial reverse-electrodialysis electrolysis cells (MRECs)}

Reverse electrodialysis (RED) generates power from the salinity gradient that develops between sea water and fresh water using a series of CEM and AEM. The chemical potential difference prevailing between salt and fresh water generates a voltage over individual membranes and the total potential of the system is the summation of the potential differences from all membranes. Typically, RED systems use many stacked cells to have a substantial energy recovery. The process ensuing high capital expenses for the large number of membranes, and increases energy losses from pumping water through a large number of cells designed in the process. Integrating MECs with the RED system forms MREC, in which high overpotentials can be overcome through the oxidation of organic matters by anodic biocatalyst while the low voltage prevailed in MFCs can be increased due to the salinity driven potential with the RED stack (Zhang and Angelidaki, 2014). Cusick et al. (2012) reported the use of MRECs to capture salinity-gradient energy from thermolytic ammonium bicarbonate solutions generating low waste heat $\left(>40^{\circ} \mathrm{C}\right)$. Capturing salinitygradient energy from such thermolytic solutions removes the dependency of this process on seawater and freshwater availability. However, the limitation associated with MREC stack arrangement with $\mathrm{NH}_{4} \mathrm{HCO}_{3}$ is nitrogen crossover from the stack into the anode chamber resulting in contamination of anodic solution with ammonia and thus, loss of the salt solution. Designing future MRECs with bipolar membranes or a low-salt solution in the membrane stack nearest to the anode can help to minimize the above stated losses. In a study, maximum energy recovery with acetate reached $30 \pm 0.5 \%$ with a power density of $5.6 \mathrm{~W} / \mathrm{m}^{2}$ (with respect to cathode surface area), which was five times that produced without the dialysis stack (Cusick et al., 2012). Furthermore, as a solution to the nitrogen crossover problem, Wallack et al. (2015) proposed the use of additional low concentration chamber before the anode using an additional AEM adjacent to similar AEM, and filled with varied amounts of both anion or cation ion exchange resins. $\mathrm{N}_{2}$ crossover to the anodic chamber was reduced by up to $97 \%$ using $50 \%$ of the chamber filled with an anion exchange resin than control, in which no additional chamber was present. Moreover, loss of power in the MREC due to this additional chamber near the anode could be overcome by placing a pair of additional membranes to enhance the stack voltage (Wallack et al., 2015). Another variation of MREC, called microbial reverse-electrodialysis chemical-production cell (MRCC) was designed by Zhu et al. (2013). MRCC produced acid and alkali by utilizing the energy produced from organic matter (acetate) and salinity gradients (seawater and river water simulated with different concentrations of sodium chloride). No external power supply was required because this system itself produced the stipulated electricity $\left(908 \mathrm{~mW} / \mathrm{m}^{2}\right)$. Fed-batch cycle operation resulted in the production of $1.35 \mathrm{mmol}$ of acid $(\mathrm{pH}, 1.65 \pm 0.04)$ and $0.59 \mathrm{mmol}$ of alkali $(\mathrm{pH}$, $11.98 \pm 0.10$ ) (Zhu et al., 2013).

\subsection{Integration of $M E C$ with anaerobic digestion $(A D)$}

$\mathrm{AD}$ is carried out through the anaerobic bacterial/archaeal metabolisms breaking down biodegradable materials and generates methane gas. This is a well-known technology and has been commercially used for simultaneous methane generation and waste/wastewater treatment (Batstone and Virdis, 2014). Electrochemical technologies and AD can be integrated for increased efficiency with the stillage released from the latter process used in the former as feedstock and energy resource recovered from the former used in the latter (Sadhukhan et al., 2016). Bo et al. (2014) inserted a pair of MEC electrodes in an anaerobic digester and generated $\mathrm{H}_{2}$ at the cathode which subsequently reacted with carbon dioxide to produce methane in-situ by the action of hydrogenotrophic methanogens. Compared to the conventional anaerobic digesters, the MEC-anaerobic digester system achieved higher methane content (up to 98\%). In this system, along with 24-230\% improvement in methane yield, substrate (COD) degradation and carbon recovery were also enhanced by $130-300 \%$ and $55-56 \%$, respectively, compared with the conventional AD reactor (Bo et al., 2014) (Table 1). In another study, an up-flow anaerobic bioelectrochemical (UABE) reactor was compared with an up-flow anaerobic sludge blanket (UASB) reactor for the treatment of acidic distillery wastewater to produce methane (Feng et al., 2016). The UABE was poised at $300 \mathrm{mV}$ and both UASB and UABE were operated in continuous mode. The integration, i.e., UABE, resulted in an improved $\mathrm{CH}_{4}$ yield of $407 \mathrm{~mL} / \mathrm{g} \mathrm{COD}_{\mathrm{r}}$ at $4.0 \mathrm{~g} \mathrm{COD} / \mathrm{L} . d$, which was significantly higher than that of UASB $\left(282 \mathrm{~mL} / \mathrm{g} \mathrm{COD}_{\mathrm{r}}\right)($ Feng et al., 2016). De Vrieze et al. (2014) tried to evaluate the plausible mechanism behind the improved performance of $\mathrm{AD}$ by inserting an MEC system into the reactor. They reported increased stability of the $\mathrm{AD}$ treating molasses by inserting electrodes and poising them at 0.75 and $1.205 \mathrm{~V}$. In the control reactors, $\mathrm{CH}_{4}$ production reduced to $50 \%$ of the initial rate (on day 91), while it remained stable in the MEC-AD reactors indicating a stabilizing effect. Interestingly, when the electrodes from these reactors were inserted in the control reactors, the methane production increased by 3-4 times. This revealed that the electroactive biofilm formed on the electrode surface must have enhanced the stability of the AD rather than the electrical current (De Vrieze et al., 2014). Similarly, Liu et al. (2016) combined MEC and AD to form an MEC-AD system to improve $\mathrm{CH}_{4}$ production rate (MPR) from waste activated sludge. MPR was enhanced to $91.8 \mathrm{~g} \mathrm{CH}_{4} / \mathrm{m}^{3}$ reactor $/ \mathrm{d}$ in the integrated MEC-AD reactor, compared to $30.6 \mathrm{~g} \mathrm{CH}_{4} / \mathrm{m}^{3}$ reactor $/ \mathrm{d}$ in the $\mathrm{AD}$ alone (Liu et al., 2016). A novel combination of AD and MEC was also designed by Cai et al. (2016) in which, two anaerobic digesters were separated by AEM, and each functioned as an electrode chamber, i.e., anode and cathode. With sludge fermentation liquid, $0.247 \mathrm{~mL} \mathrm{CH}_{4} / \mathrm{mL}_{\text {reactor }} / \mathrm{d}$ was produced at the cathodic anaerobic digester (increased by $51.53 \%$ than control) (Cai et al., 2016). Thus, methane production was enhanced with improving reactor stability, while lower contamination was observed by combining the MEC with AD (Clauwaert et al., 2008; Tartakovsky et al., 2011). Combining MEC with AD is an excellent example of how MECs can be used in a modular way to enhance the productivity of an existing technology (Aryal et al., 2018). 


\subsection{Integration of $M E C$ with anaerobic membrane bioreactor $(M B R)$}

The term membrane bioreactor (MBR) is used to define wastewater treatment processes where a perm-selective/semipermeable membrane (for example microfiltration or ultrafiltration) is integrated with a suspended growth bioreactor. Membrane filtration can be integrated into bio-electrochemical systems (BES) in the following ways: (a) as a separator between the electrodes, (b) an internal filtration component in the anode/cathode compartment, or (c) an external treatment process before or after the BES. More efficient treatment (more favorable quality of treated water), high energy efficiency, reduced investment, and mitigated fouling and/or sustainable desalination are the advantages of such integration systems (Table 1) (Yuan and He, 2015). Katuri et al. (2014) developed a novel anaerobic treatment system named as anaerobic electrochemical membrane bioreactor (AnEMBR); a combination of MEC with membrane filtration phenomenon employing electrically conductive, porous, nickel-based hollow-fiber membranes (Ni-HFMs) (Fig. 5). The AnEMBR was employed for the treatment of low organic strength wastewaters/solutions and to recover biogas (energy). The Ni-HFM served two different functions as cathode electrode for $\mathrm{H}_{2}$ production and as membrane to filter the treated water. Removal of COD (initial COD: $320 \mathrm{mg} / \mathrm{L}$ ) was $>95 \%$ and up to $71 \%$ of the substrate energy was recovered $\left(\mathrm{CH}_{4}\right.$-rich biogas, $\left.83 \%\right)$ at an applied potential of $700 \mathrm{mV}$. Additionally, there was less membrane fouling observed in the AnEMBR than in the control reactor (open circuit), which was due to $\mathrm{H}_{2}$ bubble formation, low cathode potential, and localized high $\mathrm{pH}$ at the cathode surface, (Katuri et al., 2014). In another study, a pilot scale submerged membrane electro-bioreactor (SMEBR) was operated based on the interaction between biological processes and membrane filtration for the treatment of wastewater, and electrokinetic processes were assessed (Hasan et al., 2012). A current density of $12 \mathrm{~A} / \mathrm{m}^{2}$ was maintained in the SMEBR which was operated in 235 $\mathrm{L}$ volume, at an HRT of $11 \mathrm{~h}$ for 7 weeks. In a single chamber, municipal wastewater was first treated biologically where most of COD and ammonia were removed followed by phosphorus, and flocs were coagulated in the electrical zone. Later the treated water (effluent) was filtered with a hollow fiber Microza microfiltration membrane module placed at the center of the SMEBR. The integrated system exhibited a superior function (phosphorus removal of $99 \%$, ammonia removal of $99 \%$, and COD removal of $92 \%$ ), over MBR (phosphorus removal of 59\%, ammonia removal of $97 \%$, and COD removal of $87 \%$ ) (Hasan et al., 2012). Although coupling an MBR with MEC has many potential benefits, more insights about of energy generation and consumption in the coupled system are needed.

\subsection{MEC-pressure retarded osmosis (PRO) system}

MEC systems require energy input in form of electricity to function and synthesize desired products. Combining MECs with renewable sources of energy can make the whole process more sustainable and eco-friendlier. Pressure retarded osmosis (PRO) is a technique to separate a solvent from a solution that is more concentrated and also pressurized through a semipermeable membrane. The salinity gradient generated during PRO can be used for electricity production, as also in the RED systems (see Section 4.6). Thus, the PRO unit can reduce the volume of wastewater and extract treated water. Further, the effluents from PRO unit can be treated by the MEC; and the osmotic energy obtained from the PRO unit can be integrated into the MEC for sustainable $\mathrm{H}_{2}$ production. A proof-of-concept for this system was demonstrated by Yuan et al. (2015). They first developed a time dependent PRO model and a batch model for MEC. Subsequently, using the predicted water flux obtained from the PRO model, the anolyte and the catholyte were prepared for an MEC operated experimentally using a power supply to mimic the energy supply process. The MEC system removed approx. $94 \%$ of the organics at $800 \mathrm{mV}$ and produced $32.8 \mathrm{~mL} \mathrm{H}_{2}$ at the expense of $470 \mathrm{~J}$ of energy after $46.9 \mathrm{~h}$. The PRO unit produced $579 \mathrm{~J}$ of energy, demonstrating that such a system could be effectively used to power MECs. Thus, PRO-MEC system can help with organics removal, $\mathrm{H}_{2}$ production, and water recovery simultaneously (Yuan et al., 2015).

\subsection{Integration of MEC with acidogenic bioreactor}

Similar to combining AD with MEC (see Section 4.7), acidogenic bioreactors can also be combined with MECs. Biohydrogen production was evaluated using acetate, butyrate, and propionate as substrates in a single chamber MEC by applying different voltages by Babu et al. (2013b). Maximum HPR of $2.42 \mathrm{mmol} / \mathrm{h}$ was recorded at $600 \mathrm{mV}$ along with about $53 \%$ removal of synthetic acids (Babu et al., 2013a). Furthermore, acidogenic bioreactor was also combined with MEC by the same group of researchers to improve product recovery and $\mathrm{H}_{2}$ yield (Babu et al., 2013b) (Table 1). MEC was operated at VFAs concentration of $3000 \mathrm{mg} / \mathrm{L}$ under different poised potentials with a maximum HPR of $0.53 \mathrm{mmol} / \mathrm{h}$ and $49.8 \%$ VFA utilization being observed at $600 \mathrm{mV}$ (Babu et al., 2013b). In another study, a novel bio-electrohydrolysis (BEH) system based on selfinducing electrogenic activity was designed as a pretreatment device to improve $\mathrm{H}_{2}$ production efficiency through the treatment of food waste

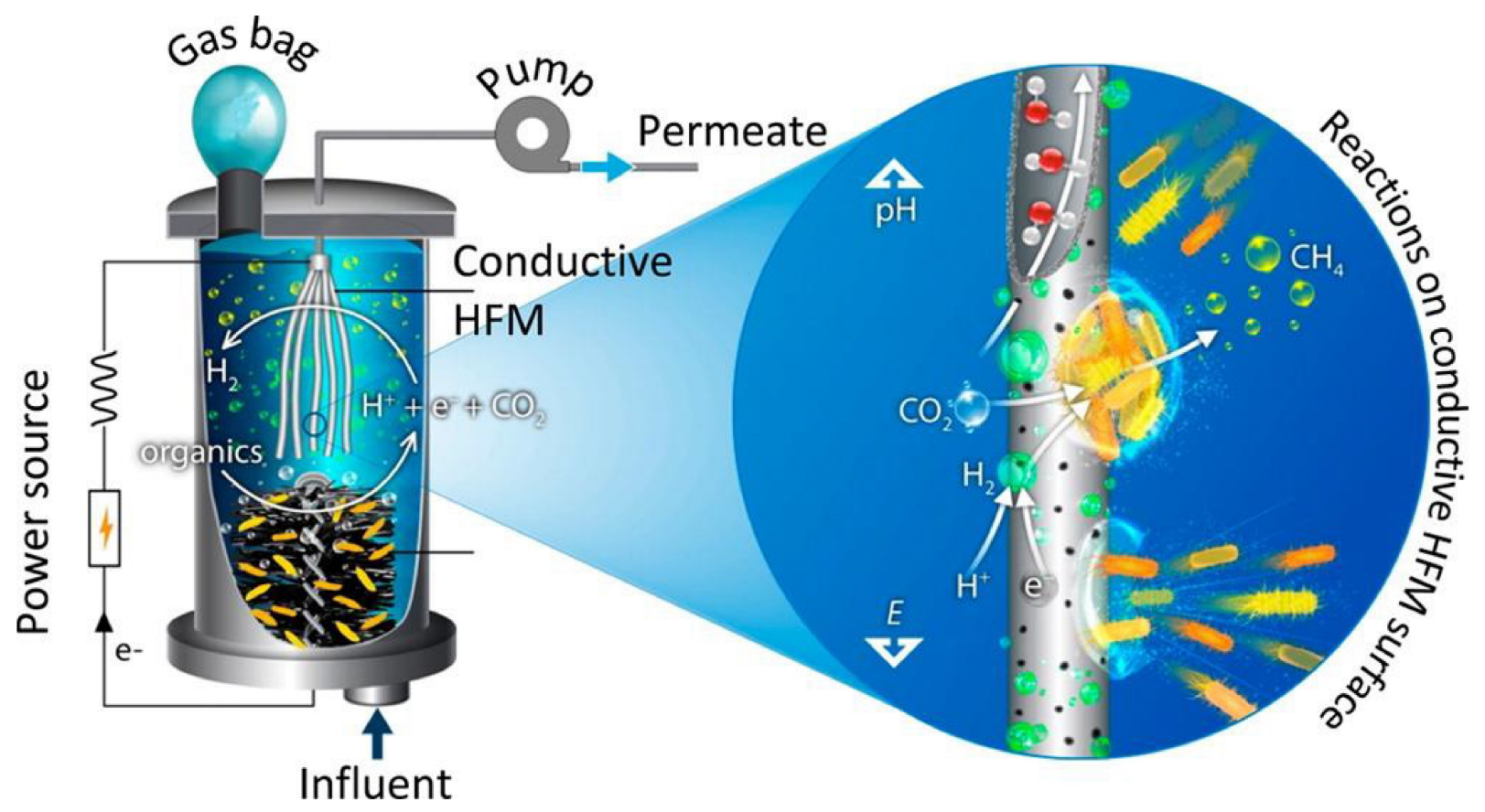

Fig. 5. Novel membrane bioreactor with conductive hollow-fiber membrane for treatment of low-organic strength solutions (Katuri et al., 2014). With permission from ACS. Copyright $\odot ~ 2014$. 
(Chandrasekhar and Mohan, 2014). A two-stage integrated or hybrid system with hydrolysis (first stage) followed by acidogenic fermentation for $\mathrm{H}_{2}$ production (second stage) was used. As a result of pretreatment, $\mathrm{BEH}$ showed a higher $\mathrm{H}_{2}$ production $(29.12 \mathrm{~mL} / \mathrm{h})$ than the control $(26.75 \mathrm{~mL} / \mathrm{h})$. Additionally, substrate degradation also improved with the BEH-pretreated substrate (COD removal of 52.42\%) over the control (COD removal of 43.68\%) (Chandrasekhar and Mohan, 2014). Modestra et al. (2015) also designed a single chambered MEC with acid pretreated biocatalyst, for electrofermentation of effluents towards additional $\mathrm{H}_{2}$ production with simultaneous treatment. The effect of VFA concentration $(4000 \mathrm{mg} / \mathrm{L}$ and $8000 \mathrm{mg} / \mathrm{L})$ on biohydrogen production with simultaneous remediation was studied at $200 \mathrm{mV}$ and $600 \mathrm{mV}$ applied potential. Maximum HPR of $0.057 \mathrm{mmol} / \mathrm{h}$ was observed at $600 \mathrm{mV}$ along with a VFA utilization of $68 \%$ (Modestra et al., 2015). Thus, by combining MEC with acidogenic reactors, waste effluent from such reactors could be potentially converted into useful products like $\mathrm{H}_{2}$.

4.11. Integration of MEC with microbial electrolysis and desalination cell (MEDC)

A BES system developed by combining microbial electrolysis and desalination cell (MEDC) can concurrently reduce the salinity of salt water and produce $\mathrm{H}_{2}$. The benefit of MEDC is that it can generate pure and collectable $\mathrm{H}_{2}$ gas without dealing with contamination or voltage fluctuation and can achieve improved desalination assisted by an external power supply (Saeed et al., 2015). Mehanna et al. (2010) developed a three chambered MEDC consisting of an anode, desalination and cathode chambers, by using a pair of ion exchange membranes. Maximum HPR of $0.16 \mathrm{~m}^{3} \mathrm{H}_{2} / \mathrm{m} 3 / \mathrm{d}$ was obtained in this reactor at an applied voltage of $550 \mathrm{mV}$ (Table 1). Also, the conductivity of the water in the desalination chamber decreased by $68 \pm 3 \%$ with the $5.0 \mathrm{~g} / \mathrm{L}$ $\mathrm{NaCl}$ sample and by $37 \pm 4 \%$ with the $20 \mathrm{~g} / \mathrm{L} \mathrm{NaCl}$ sample (Mehanna et al., 2010). Similarly, Luo et al. (2012) reported $98.8 \%$ removal of $\mathrm{NaCl}$ (initial concentration: $10 \mathrm{~g} / \mathrm{L}$ ) from the middle desalination chamber per day. Apart from $\mathrm{NaCl}$ removal, $\mathrm{H}_{2}$ production at the rate of $1.5 \mathrm{~m}^{3} / \mathrm{m}^{3} / \mathrm{d}(1.6 \mathrm{~mL} / \mathrm{h})$ was achieved at $0.8 \mathrm{~V}$ (Luo et al., 2012). Thus, MEDC systems can potentially treat saline wastewaters along with $\mathrm{H}_{2}$ production. However, due to the sharp fluctuations in $\mathrm{pH}$, exoelectrogens at anode and HPR at cathode could suffer. A solution to this problem was reported by Chen et al. (2012) who integrated an acid-production chamber and a bipolar membrane (BPM) into MEDC to form the microbial electrolysis desalination and chemical-production cell (MEDCC), which could simultaneously desalinate seawater, produce hydrochloric acid and generate $\mathrm{NaOH}$. This arrangement helped to alleviate the difficulties of $\mathrm{pH}$ fluctuations and chloride ion $\left(\mathrm{Cl}^{-}\right)$accumulation observed in a conventional MEDC. They also compared the performance of an MEDC and an MEDCC in their experiments. With the applied voltage of $1.0 \mathrm{~V}$, the coulombic efficiency values of the MEDCC and MEDC were $97 \pm 2 \%$ and $65 \pm 2 \%$, respectively. Furthermore, $86 \pm 4 \%$ and $60 \pm 4 \%$ of the $10 \mathrm{~g} / \mathrm{L} \mathrm{NaCl}$ (initial concentration) was removed in the desalination chamber of the MEDCC and MEDC, respectively, within $18 \mathrm{~h}$. Lastly, with the applied voltage of $1.0 \mathrm{~V}$ within $18 \mathrm{~h}$, the MEDCC produced $0.10 \mathrm{~g}$ of $\mathrm{NaOH}$ with $7.46 \times 10^{-5} \mathrm{kWh}$ electricity (Chen et al., 2012). Therefore, by using an MEDCC, salty water can be treated without large $\mathrm{pH}$ changes. However, more research is required to make the membranes leakproof while provisions for up-scaling also need to be explored (Zhang and Angelidaki, 2014).

\subsection{Integration of MEC with lignocellulosic ethanol biorefinery process}

Lignocellulosic ethanol production is considered as one of the important second-generation biofuels. The substrate that is generated from lignocelluloses such as wheat straw by hydrothermal treatment followed by enzymatic hydrolysis can be used to produce ethanol. This process also generates a wide range of products viz., VFAs, phenolics, xylose, and polysaccharides, exhibiting the potential to generate a considerable amount of energy. Accordingly, an MEC was coupled to harvest $\mathrm{H}_{2}$ from the effluent of lignocellulosic ethanol production which converted 60-70\% of COD to $\mathrm{H}_{2}$ (Borole and Mielenz, 2011). Moreover, during the pretreatment stage, a large number of metabolic inhibitors like furanic and phenolic compounds, furfural and hydroxymethyl furfural were generated which are critical impediments for the downstream process. Rich bacterial diversity/community developed in the system was helpful for the utilization of phenolics and polysaccharides (Zeng et al., 2015). $\mathrm{H}_{2}$ was generated in the MEC using a mixture of furfural and 5- hydroxymethyl furfural and three phenolic compounds such as syringic acid, vanillic acid, and 4-hydroxybenzoic acid as substrate in an anodic oxidation reaction. The initial concentration of $8.7 \mathrm{mM}$ of the mixture of the five compounds was used, which bio-transformed at a rate ranging from 0.85 to $2.34 \mathrm{mM} / \mathrm{d}$. The $\mathrm{H}_{2}$ yield varied in the range of 0.26 to $0.42 \mathrm{~g} \mathrm{H}_{2-}$ COD/g COD removed through the anodic reaction (Zeng et al., 2015). The concept of biorefineries could also be beneficial for polyphenol purification as well as for targeted modification of fruit-based phenolics. As waste products can be directly considered as substrate input for an MES, the combination of an ethanol biorefinery process could allow the maximization of the energy output and simultaneous valorization of the ethanol waste stream (Fig. 6) (Thygesen et al., 2010).

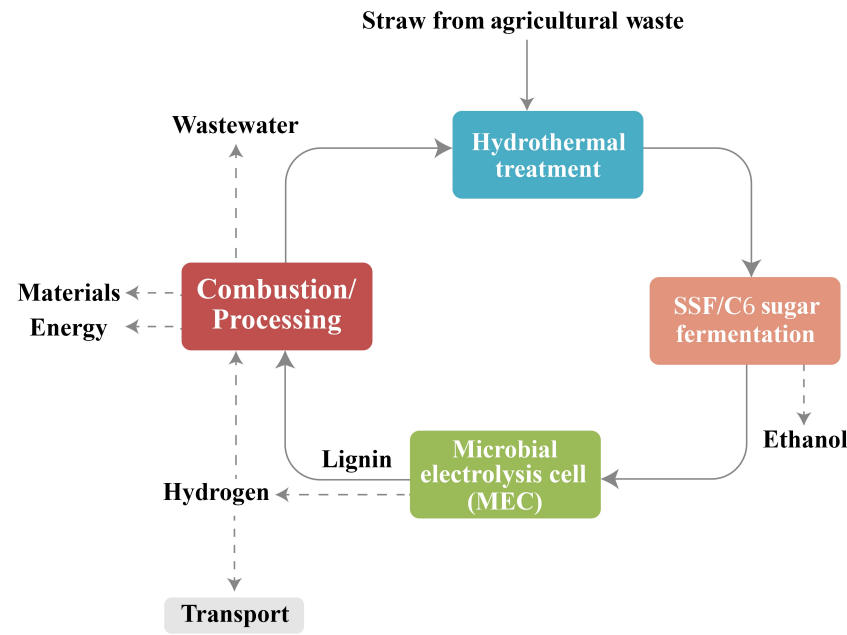

Fig. 6. Overall concept of integrating an MEC with a lignocellulosic ethanol biorefinery for further processing and valorization of the waste stream of bioethanol production. Redrawn from Thygesen et al. (2010). With permission from Springer Nature. Copyright $\odot 2010$.

\subsection{Thermoelectric microconverter-MEC coupled system}

Industrial processes viz., automobile industries, steel industries, etc., generate waste heat as by-product which can be tapped as an energy source by thermoelectric converters and this energy is called as thermoelectricity. This phenomenon is called as Seebeck effect and was discovered in 1821 (Elsheikh et al., 2014). Thermoelectricity converters function based on the temperature gradient that exists in the medium, which can be water or any solid phases. Industrial activities generate a large amount of heat and that could create a temperature gradient, which could help with thermoelectricity generation. Thermoelectricity can also be captured from low temperatures on which limited studies are available. Recovery of waste heat from such low temperatures is more environmentally friendly. MECs operation for the production of $\mathrm{H}_{2}$ requires low amounts of electrical energy. Thermoelectricity is renewable in nature. Thus, the integration of MECs with thermoelectricity can make the $\mathrm{H}_{2}$ production process more sustainable. Chen et al. (2016) evaluated the effects of different temperature ranges in a thermoelectric microconverter-MEC coupled system on $\mathrm{H}_{2}$ production from acetate as carbon source. HPR of the systems was found to depend on the generated electric potential by the thermoelectric microconverter. Based on the temperature (between 35 to $55^{\circ} \mathrm{C}$ ), the voltage varied between $170 \mathrm{mV}$ to $830 \mathrm{mV}$. Maximum $\mathrm{H}_{2}$ production of $0.16 \mathrm{~m}^{3} / \mathrm{m}^{3} / \mathrm{d}$ and yield of $2.7 \mathrm{~mol} / \mathrm{mol}_{\text {acetate }}$ were recorded at $55^{\circ} \mathrm{C}$ of the hot side, where an average voltage of $700 \mathrm{mV}$ was sustained with the current density in the range of 0.28 to $1.10 \mathrm{~A} / \mathrm{m}^{2}$ (Chen et al., 2016).

\section{Existing challenges and limitations to scaling-up the MEC technology}

Bringing the MEC technique into a pilot or industrial scale is still a challenge. MECs, as being a newly developed technique in the past decade, 


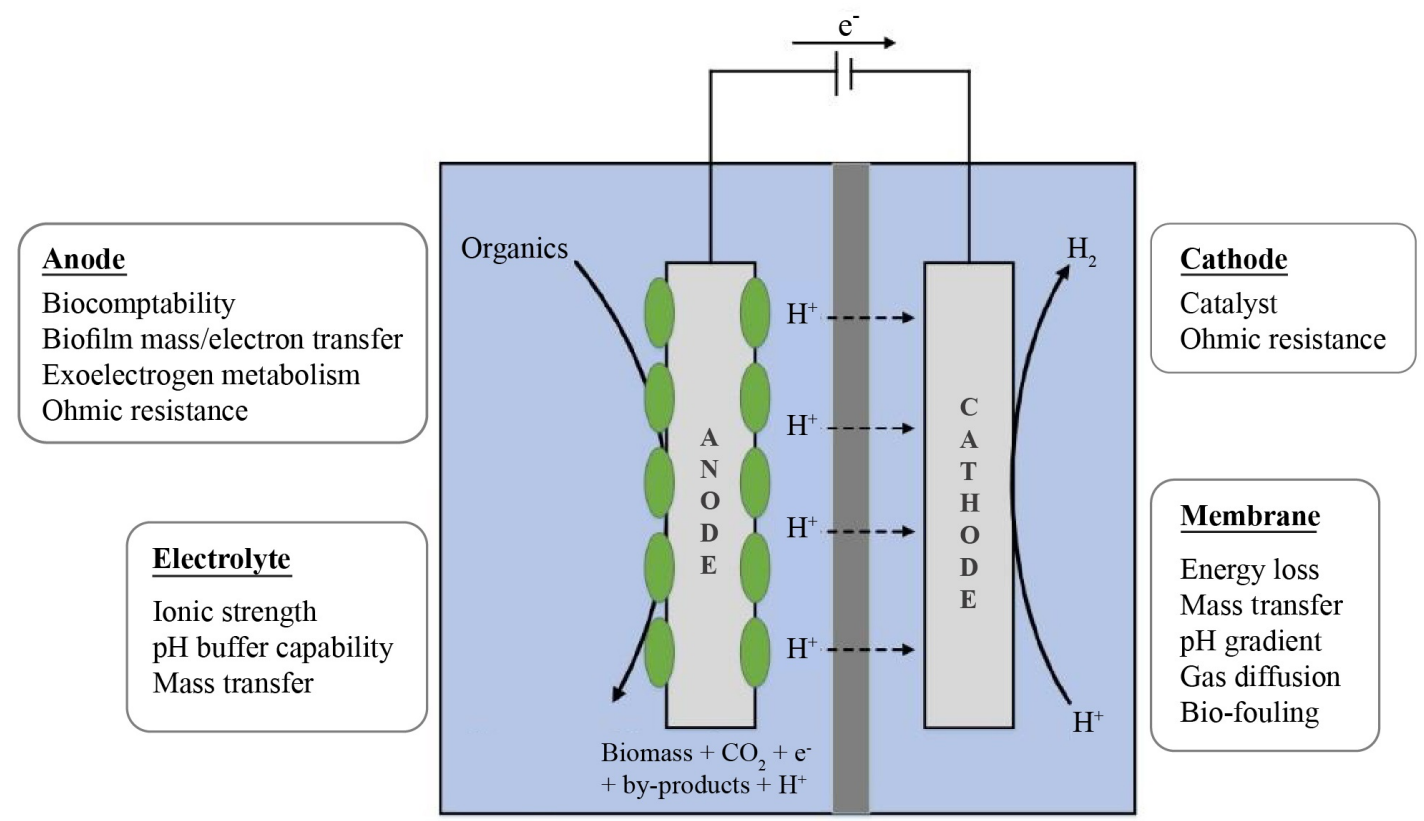

Fig. 7. Key factors influencing the components of microbial electrolysis cell (MEC) during the scale-up of the process.

Table 2.

Comparison of the present review with the review articles previously published on MEC (2013-2019).

\begin{tabular}{|c|c|c|c|c|c|c|c|c|c|c|c|c|c|}
\hline \multirow{2}{*}{ Reference } & \multicolumn{13}{|c|}{ Different types of MEC integration } \\
\hline & $\mathbf{A}^{*}$ & B & C & D & $\mathbf{E}$ & $\mathbf{F}$ & G & H & I & $\mathbf{J}$ & $\mathbf{K}$ & $\mathbf{L}$ & M \\
\hline This Study & $\checkmark$ & $\checkmark$ & $\checkmark$ & $\checkmark$ & $\checkmark$ & $\checkmark$ & $\checkmark$ & $\checkmark$ & $\checkmark$ & $\checkmark$ & $\checkmark$ & $\checkmark$ & $\checkmark$ \\
\hline Hua et al. (2019) & $\checkmark$ & $x$ & $\times$ & $x$ & $\times$ & $\times$ & $\checkmark$ & $x$ & $x$ & $x$ & $\checkmark$ & $x$ & $x$ \\
\hline Katuri et al. (2019) & $\checkmark$ & $\times$ & $\times$ & $\checkmark$ & $\times$ & $x$ & $\checkmark$ & $\checkmark$ & $x$ & $x$ & $x$ & $\checkmark$ & $\checkmark$ \\
\hline Yang et al. (2019) & $\times$ & $\checkmark$ & $x$ & $x$ & $\times$ & $\checkmark$ & $x$ & $x$ & $\checkmark$ & $x$ & $\checkmark$ & $x$ & $x$ \\
\hline Bakonyi et al. (2018) & $\times$ & $\times$ & $\times$ & $\checkmark$ & $\times$ & $x$ & $x$ & $x$ & $x$ & $x$ & $x$ & $x$ & $x$ \\
\hline Jiang et al. (2018) & $x$ & $x$ & $\checkmark$ & $x$ & $x$ & $\checkmark$ & $\checkmark$ & $\checkmark$ & $x$ & $\times$ & $\times$ & $x$ & $x$ \\
\hline Li et al. (2018) & $\times$ & $\checkmark$ & $\times$ & $\times$ & $\times$ & $x$ & $\times$ & $x$ & $x$ & $x$ & $\checkmark$ & $x$ & $x$ \\
\hline Sivagurunathan et al. (2018) & $\checkmark$ & $x$ & $x$ & $\checkmark$ & $x$ & $x$ & $x$ & $x$ & $x$ & $x$ & $x$ & $x$ & $x$ \\
\hline Yu et al. (2018) & $\times$ & $\times$ & $\times$ & $\times$ & $\times$ & $x$ & $\checkmark$ & $x$ & $x$ & $x$ & $x$ & $x$ & $x$ \\
\hline Bundhoo (2017) & $\checkmark$ & $x$ & $\times$ & $\checkmark$ & $\times$ & $x$ & $\checkmark$ & $x$ & $x$ & $x$ & $x$ & $x$ & $x$ \\
\hline Khan et al. (2017) & $x$ & $x$ & $\checkmark$ & $\checkmark$ & $\times$ & $x$ & $\checkmark$ & $x$ & $x$ & $\times$ & $x$ & $x$ & $x$ \\
\hline Zhen et al. (2017) & $\times$ & $x$ & $\times$ & $x$ & $\times$ & $\checkmark$ & $\checkmark$ & $x$ & $\times$ & $x$ & $\checkmark$ & $x$ & $x$ \\
\hline Escapa et al. (2016) & $x$ & $\checkmark$ & $\times$ & $x$ & $\times$ & $x$ & $\checkmark$ & $x$ & $x$ & $x$ & $\checkmark$ & $x$ & $x$ \\
\hline Sadhukhan et al. (2016) & $x$ & $\times$ & $\times$ & $x$ & $\times$ & $x$ & $\checkmark$ & $x$ & $x$ & $x$ & $x$ & $\checkmark$ & $x$ \\
\hline Lu and Ren (2016) & $x$ & $\times$ & $\times$ & $\checkmark$ & $\times$ & $\times$ & $\checkmark$ & $x$ & $x$ & $x$ & $x$ & $x$ & $x$ \\
\hline Kadier et al. (2016a) & $\checkmark$ & $x$ & $\checkmark$ & $\checkmark$ & $x$ & $\checkmark$ & $x$ & $x$ & $x$ & $x$ & $\checkmark$ & $x$ & $x$ \\
\hline Kadier et al. (2016b) & $\checkmark$ & $\times$ & $\checkmark$ & $\checkmark$ & $x$ & $\checkmark$ & $x$ & $\times$ & $\times$ & $\times$ & $\checkmark$ & $\times$ & $x$ \\
\hline Zhang et al. (2014) & $\checkmark$ & $x$ & $\checkmark$ & $\checkmark$ & $\times$ & $\checkmark$ & $x$ & $x$ & $x$ & $x$ & $\checkmark$ & $x$ & $x$ \\
\hline Zhou et al. (2013) & $\checkmark$ & $\checkmark$ & $\times$ & $\checkmark$ & $x$ & $x$ & $x$ & $x$ & $x$ & $x$ & $x$ & $x$ & $x$ \\
\hline
\end{tabular}

* A: MEC - MFC coupled system; B: Submersible Microbial Electrolysis Cell (SMEC); C: Solar powered MEC; D: Dark fermentation and MFC-MEC coupled system; E: Integration of pyrolysis with MEC; F: Microbial Reverse-Electrodialysis Electrolysis Cells (MRECs); G: Integration of MEC and Anaerobic Digestion (AD); H: Integration of MEC with anaerobic membrane bioreactor (MBR); I: MEC-Pressure Retarded Osmosis (PRO) system; J: Integration of MEC with acidogenic bioreactor; K: Integration of MEC with microbial electrolysis and desalination cell; L: Integration of MEC with lignocellulosic ethanol biorefinery process; M: Thermoelectric microconverter-MEC coupled system. 
has not been well studied at large scale yet, with only a few pilot studies reported so far (Rozendal et al., 2006; Cusick et al., 2012; Heidrich et al., 2013; Gil-Carrera et al., 2013; Escapa et al., 2016). The biggest impediment to scale up MECs (similar to the other bioelectrochemical systems) is the matter of system efficiency. More energy losses and lower specific production rates are normally observed with increases in reactor size (Escapa et al., 2016; Li et al., 2018). Some core technical challenges of each component of MEC reactors are presented in Figure 7. Firstly, there is a major challenge to maintain the electron transfer efficiency from exoelectrogens to the anode while scaling up the MEC reactors. Even though the relationship between current density and anode surface area has not been systematically quantified, it is generally accepted that the current density would decrease with increases in anode size (Dewan et al., 2008). This will reduce energy efficiency and increase the energy input cost for $\mathrm{H}_{2}$ production. Establishing a highly electrochemically active biofilm and maintaining the sufficient mass/electron transfer within the biofilm is essential.

Another important issue affecting MEC efficiency is energy losses. The first factor that causes energy loss is the $\mathrm{pH}$ gradient, which is a common issue for membrane-based MEC reactors regardless of the membrane material used (Rozendal et al., 2006). This could cause a major shift in cathode potential and interfere with anode exoelectrogen metabolism. Rozendal et al. (2006) reported that about $0.38 \mathrm{~V}$ out of $1 \mathrm{~V}$ applied in the system was lost due to the proton gradient using a CEM. The ion selection of membrane as well as the ions presented in the electrolyte and its $\mathrm{pH}$ buffering capability determine the $\mathrm{pH}$ gradient between the two compartments. It should be noted that buffering the electrolyte by chemical dosing is also impractical at the industrial scale. Therefore, a practical solution to solve this issue is highly required.

The second type of energy loss is called the ohmic energy loss, mainly originating from the ohmic resistance of anode and cathode as well as the conductivity of electrolytes and membrane. Because of their relatively lower conductivity and lower ohmic resistance, carbon-based electrodes could serve more ideally at large scale applications. Moreover, the conductivity of electrolytes is also an issue, especially when an MEC is combined with wastewater treatment. Although some wastewaters have high conductivities, such as distillery wastewater (Mohanakrishna et al., 2010), wastewater from chemical industries (Venkata Mohan et al., 2008), and source-separated urine (Ledezma et al., 2015), the majority of domestic and industrial wastewaters typically show low conductivity that could cause large ohmic losses (Jeremiasse et al., 2010). This will require shortening the distance between the two electrodes (anode and cathode) to reduce the ohmic drop, but another issue of gas diffusion will become serious in this case: either the diffusion of $\mathrm{H}_{2}$ to anode to induce the methanogens growth or the diffusion of carbon dioxide to cathode to reduce the purity of $\mathrm{H}_{2}$ gas.

In addition to the issue solely related to MEC reactors, integrating MECs with other techniques on a large scale also still challenging. Integrating with other techniques could significantly expand the potentiality of MECs and could enhance their industrial competitiveness. The major challenge of this approach is that most of the options discussed above are still in the stage of infancy and sufficient insights are lacking. Firstly, advanced system structure designs are required to meet both requirements of MECs and the other processes to be integrated. This may lead to higher costs for system construction, which needs to be compensated for by additional benefits. Furthermore, the comparability between MECs and the technique to be integrated is unclear and needs to be systematically investigated. Since the two techniques are dependent of each other, the performance of one process could exert a significant influence on that of the other. This influence could be negative if the system is not well designed. Dynamic evaluation of the configuration is also essential, especially because of the relatively low rate of MECs. Different scaling up factors, required for MEC reactors and other techniques to achieve a dynamic equilibrium status, might be problematic and need to be solved during the scaling up process.

\section{Conclusions and future prospects}

Table 2 presents a comparison between the present review and the review articles previously published on MECs (2013-2019). As seen, to the best of our knowledge, this work is the most inclusive review on the topic in particular for its coverage of the various MFC integration options.

In summary, the future of MECs seems promising in reducing the overall cost of wastewater treatment and in providing additional benefits through the production of $\mathrm{H}_{2}$ or other value-added fuels/chemicals. However, MEC technology is still in its infancy, facing some challenges which should be overcome prior to its scaling-up and commercialization. Issues like energy loss, mass transfer limitations, $\mathrm{pH}$ gradient, etc., need to be investigated systematically at pilot-scale using real-field wastewaters. Application of dynamic modeling and designing MECs having lower mass transfer limitations and energy loss are also equally important. The advantage of integrating MEC with different energy-generating processes will also improve the pace of biorefineries growth towards sustainable development.

\section{Acknowledgements}

The present work was supported by the National University of Malaysia (UKM) and the Malaysian Ministry of Higher Education (MOHE), Project No: DIP-2017-019. Special thanks to the Head of Project, Prof. Dr. Mohd Sahaid Kalil and Members.

\section{References}

[1] Abdeshahian, P., Al-Shorgani, N.K.N., Salih, N.K.M., Shukor, H., Kadier, A., Hamid, A.A., Kalil, M.S., 2014. The production of biohydrogen by a novel strain Clostridium sp. YM1 in dark fermentation process. Int. J. Hydrogen Energy. 39(24), 12524-12531.

[2] Ajayi, F.F., Kim, K.Y., Chae, K.J., Choi, M.J., Chang, I.S., Kim, I.S. 2010. Optimization studies of bio-hydrogen production in a coupled microbial electrolysis-dye sensitized solar cell system. Photochem. Photobiol. Sci. 9(3), 349-356.

[3] Aryal, N., Kvist, T., Ammam, F., Pant, D., Ottosen, L.D., 2018. An overview of microbial biogas enrichment. Bioresour. Technol. 264 359-369.

[4] Azman, N.F., Abdeshahian, P., Kadier, A., Shukor, H., Al-Shorgani, N.K.N., Hamid, A.A., Kalil, M.S., 2016. Utilization of palm kernel cake as a renewable feedstock for fermentative hydrogen production. Renewable Energy. 93, 700-708

[5] Babu, M.L., Sarma, P.N., Mohan, S.V., 2013. Microbial electrolysis of synthetic acids for biohydrogen production: influence of biocatalyst pretreatment and $\mathrm{pH}$ with the function of applied potential. J. Microb. Biochem. Technol. S6, 2

[6] Babu, M.L., Subhash, G.V., Sarma, P.N., Mohan, S.V., 2013. Bioelectrolytic conversion of acidogenic effluents to biohydrogen: an integration strategy for higher substrate conversion and product recovery. Bioresour. Technol. 133, 322-331.

[7] Bakonyi, P., Kumar, G., Koók, L., Tóth, G., Rózsenberszki, T. Bélafi-Bakó, K., Nemestóthy, N., 2018. Microbial electrohydrogenesis linked to dark fermentation as integrated application for enhanced biohydrogen production: a review on process characteristics, experiences and lessons. Bioresour. Technol. 251, 381-389.

[8] Bartels, J.R., Pate, M.B., Olson, N.K., 2010. An economic survey of hydrogen production from conventional and alternative energy sources. Int. J. Hydrogen Energy. 35(16), 8371-8384

[9] Batstone, D.J., Virdis, B., 2014. The role of anaerobic digestion in the emerging energy economy. Curr. Opin. Biotechnol. 27, 142-149.

[10] Bo, T., Zhu, X., Zhang, L., Tao, Y., He, X., Li, D., Yan, Z., 2014. A new upgraded biogas production process: coupling microbial electrolysis cell and anaerobic digestion in single-chamber, barrelshape stainless steel reactor. Electrochem. Commun. 45, 67-70.

[11] Borole, A.P., 2015. Sustainable and efficient pathways for bioenergy recovery from low-value process streams via bioelectrochemical systems in biorefineries. Sustainability. 7(9), 11713-11726.

[12] Borole, A.P., Mielenz, J.R., 2011. Estimating hydrogen production potential in biorefineries using microbial electrolysis cell technology. Int. J. Hydrogen Energy. 36(22), 14787-14795.

[13] Bundhoo, Z.M.A., 2017. Coupling dark fermentation with biochemical or bioelectrochemical systems for enhanced bio-energy production: a review. Int. J. Hydrogen Energy. 42(43), 26667-26686.

[14] Cai, W., Han, T., Guo, Z., Varrone, C., Wang, A., Liu, W., 2016. Methane production enhancement by an independent cathode in integrated anaerobic reactor with microbial electrolysis. Bioresour. Technol. 208, 13-18 
[15] Call, D., Logan, B.E., 2008. Hydrogen production in a single chamber microbial electrolysis cell lacking a membrane. Environ. Sci. Technol. 42(9), 3401-3406.

[16] Cerrillo, M., Viñas, M., Bonmatí, A., 2016. Overcoming organic and nitrogen overload in thermophilic anaerobic digestion of pig slurry by coupling a microbial electrolysis cell. Bioresour. Technol. 216, 362-372.

[17] Chae, K., Choi, M., Chang, I., Kim, I.N.S., 2009. A solar-powered microbial electrolysis cell with a platinum catalyst-free cathode to produce hydrogen. Environ. Sci. Technol. 43(24), 9525-9530.

[18] Chandrasekhar, K., Mohan, S.V., 2014. Bio-electrohydrolysis as a pretreatment strategy to catabolize complex food waste in closed circuitry: function of electron flux to enhance acidogenic biohydrogen production. Int. J. Hydrogen Energy. 39(22), 11411-11422.

[19] Chen, S., Liu, G., Zhang, R., Qin, B., Luo, Y., 2012. Development of the microbial electrolysis desalination and chemical-production cell for desalination as well as acid and alkali productions. Environ. Sci. Technol. 46(4), 2467-2472.

[20] Chen, Y., Chen, M., Shen, N., Zeng, R.J., 2016. $\mathrm{H}_{2}$ production by the thermoelectric microconverter coupled with microbial electrolysis cell. Int. J. Hydrogen Energ. 41(48), 22760-22768.

[21] Clauwaert, P., Toledo, R., van der Ha, D., Crab, R., Verstraete, W., Hu, H., Udert, K.M., Rabaey, K., 2008. Combining biocatalyzed electrolysis with anaerobic digestion. Water Sci. Technol. 57(4), 575-579.

[22] Cusick, R.D., Kim, Y., Logan, B.E., 2012. Energy capture from thermolytic solutions in microbial reverse-electrodialysis cells. Science. 335(6075), 1474-1477

[23] De Vrieze, J., Gildemyn, S., Arends, J.B. Vanwonterghem, I., Verbeken, K., Boon, N., Verstraete, W., Tyson, G.W., Hennebel, T., Rabaey, K., 2014. Biomass retention on electrodes rather than electrical current enhances stability in anaerobic digestion. Water Res. 54, 211-221.

[24] Deval, A.S., Parikh, H.A., Kadier, A., Chandrasekhar, K., Bhagwat, A.M., Dikshit, A.K., 2017. Sequential microbial activities mediated bioelectricity production from distillery wastewater using bioelectrochemical system with simultaneous waste remediation. Int. J. Hydrogen Energy. 42(2), 1130-1141

[25] Dewan, A., Beyenal, H., Lewandowski, Z., 2008. Scaling up microbial fuel cells. Environ. Sci. Technol. 42(20), 7643-7648.

[26] Dhar, B.R., Elbeshbishy, E., Hafez, H., Lee, H.S., 2015. Hydrogen production from sugar beet juice using an integrated biohydrogen process of dark fermentation and microbial electrolysis cell. Bioresour. Technol. 198, 223-230.

[27] Elsheikh, M.H., Shnawah, D.A., Sabri, M.F.M., Said, S.B.M., Hassan, M.H., Bashir, M.B.A., Mohamad, M., 2014. A review on thermoelectric renewable energy: Principle parameters that affect their performance. Renew. Sust. Energy Rev. 30, 337-355.

[28] Escapa, A., Mateos, R., Martínez, E.J., Blanes, J., 2016. Microbial electrolysis cells: an emerging technology for wastewater treatment and energy recovery. From laboratory to pilot plant and beyond. Renew. Sust. Energy Rev. 55, 942-956.

[29] Feng, Q., Song, Y., Yoo, K., Lal, B., Kuppanan, N., Subudhi, S., Choi, T.S., 2016. Performance of upflow anaerobic bioelectrochemical reactor compared to the sludge blanket reactor for acidic distillery wastewater treatment. J. Korean Soc. Environ. Eng. 38(6), 279-290.

[30] Fischer, F., 2018. Photoelectrode, photovoltaic and photosynthetic microbial fuel cells. Renew. Sust. Energy Rev. 90, 16-27.

[31] Gil-Carrera, L., Escapa, A., Mehta, P., Santoyo, G., Guiot, S.R., Morán, A., Tartakovsky, B., 2013. Microbial electrolysis cell scale-up for combined wastewater treatment and hydrogen production. Bioresour. Technol. 130, 584-591.

[32] Hasan, S.W., Elektorowicz, M., Oleszkiewicz, J.A., 2012. Correlations between trans-membrane pressure (TMP) and sludge properties in submerged membrane electro-bioreactor (SMEBR) and conventional membrane bioreactor (MBR). Bioresour. Technol. 120, 199-205.

[33] Heidrich, E.S., Edwards, S.R., Dolfing, J., Cotterill, S.E., Curtis, T.P., 2014. Performance of a pilot scale microbial electrolysis cell fed on domestic wastewater at ambient temperatures for a 12 month period. Bioresour. Technol. 173, 87-95.

[34] Hua, T., Li, S., Li, F., Zhou, Q., Ondon, B.S., 2019. Microbial electrolysis cell as an emerging versatile technology: a review on its potential application, advance and challenge. J. Chem. Technol. Biotechnol. 94(6), 1697-1711.

[35] Jiang, Y., Zeng, R.J., 2018. Expanding the product spectrum of value added chemicals in microbial electrosynthesis through integrated process design — a review. Bioresour. Technol. 269, 503-512.

[36] Jeremiasse, A.W., Hamelers, H.V., Buisman, C.J., 2010. Microbial electrolysis cell with a microbial biocathode. Bioelectrochemistry. 78(1), 39-43.

[37] Kadier, A., Simayi, Y., Kalil, M.S., Abdeshahian, P., Hamid, A.A., 2014. Review of the substrates used in microbial electrolysis cells (MECs) for producing sustainable and clean hydrogen gas. Renew. Energy. 71, 466-472.

[38] Kadier, A., Simayi, Y., Chandrasekhar, K., Ismail, M., Kalil, M.S. 2015. Hydrogen gas production with an electroformed Ni mesh cathode catalysts in a single-chamber microbial electrolysis cell (MEC). Int. J. Hydrogen Energy. 40(41), 14095-14103.

[39] Kadier, A., Kalil, M.S., Abdeshahian, P., Chandrasekhar, K. Mohamed, A., Azman, N.F., Logroño, W., Simayi, Y., Hamid, A.A., 2016a. Recent advances and emerging challenges in microbia electrolysis cells (MECs) for microbial production of hydrogen and value-added chemicals. Renew. Sust. Energy Rev. 61, 501-525.

[40] Kadier, A., Simayi, Y., Abdeshahian, P., Azman, N.F., Chandrasekhar, K., Kalil, M.S., 2016b. Comprehensive review of microbial electrolysis cells (MEC) reactor designs and configurations for sustainable hydrogen gas production. Alexandria Eng. J. 55(1), 427-443.

[41] Katuri, K.P., Ali, M., Saikaly, P.E., 2019. The role of microbial electrolysis cell in urban wastewater treatment: integration options, challenges, and prospects. Curr. Opin. Biotechnol. 57, 101-110.

[42] Katuri, K.P., Werner, C.M., Jimenez-sandoval, R.J., Chen, W., Jeon, S., Logan, B.E., Lai, Z., Amy, G.L., Saikaly, P.E., 2014. A Novel Anaerobic Electrochemical Membrane Bioreactor (AnEMBR) with Conductive Hollow- fi ber Membrane for Treatment of Low- Organic Strength Solutions. Environ. Sci. Technol. 48(21), 12833-12841.

[43] Khan, M.Z., Nizami, A.S., Rehan, M., Ouda, O.K.M., Sultana, S., Ismail, I.M., Shahzad, K., 2017. Microbial electrolysis cells for hydrogen production and urban wastewater treatment: a case study of Saudi Arabia. Appl. Energy. 185, 410-420.

[44] Khanna, N., Das, D., 2013. Biohydrogen production by dark fermentation. Wiley Interdiscip. Rev. Energy Environ. 2(4), 401-421.

[45] Kumar, G., Saratale, R.G., Kadier, A., Sivagurunathan, P., Zhen, G., Kim, S.H., Saratale, G.D., 2017. A review on bio-electrochemical systems (BESs) for the syngas and value added biochemicals production. 177, 84-92.

[46] Ledezma, P., Kuntke, P., Buisman, C.J., Keller, J., Freguia, S., 2015 Source-separated urine opens golden opportunities for microbial electrochemical technologies. Trends Biotechnol. 33(4), 214-220.

[47] Lee, M.Y., Kim, K.Y., Yang, E., Kim, I.S., 2015. Evaluation of hydrogen production and internal resistance in forward osmosis membrane integrated microbial electrolysis cells. Bioresour. Technol. $187,106-112$.

[48] Lewis, A.J., Ren, S., Ye, X., Kim, P., Labbe, N., Borole, A.P., 2015 Hydrogen production from switchgrass via an integrated pyrolysismicrobial electrolysis process. Bioresour. Technol. 195, 231-241.

[49] Li, S., Chen, G., Anandhi, A., 2018. Applications of emerging bioelectrochemical technologies in agricultural systems: a current review. Energies. 11(11), 2951.

[50] Li, X.H., Liang, D.W., Bai, Y.X., Fan, Y.T., Hou, H.W., 2014 Enhanced $\mathrm{H}_{2}$ production from corn stalk by integrating dark fermentation and single chamber microbial electrolysis cells with double anode arrangement. Int. J. Hydrogen Energy. 39(17), $8977-$ 8982.

[51] Liu, H., Grot, S., Logan, B.E., 2005. Electrochemically assisted microbial production of hydrogen from acetate. Environ. Sci. Technol. 39(11), 4317-4320.

[52] Liu, W., Cai, W., Guo, Z., Wang, L., Yang, C., Varrone, C., Wang, A., 2016. Microbial electrolysis contribution to anaerobic digestion of waste activated sludge, leading to accelerated methane production. Renew. Energy. 91, 334-339. 
[53] Lu, L., Ren, Z.J., 2016. Microbial electrolysis cells for waste biorefinery: a state of the art review. Bioresour. Technol. 215, 254-264.

[54] Luo, H., Xu, P., Roane, T.M., Jenkins, P.E., Ren, Z., 2012. Microbial desalination cells for improved performance in wastewater treatment, electricity production, and desalination. Bioresour. Technol. 105, 60-66.

[55] McGlade, C., Ekins, P., 2015. The geographical distribution of fossil fuels unused when limiting global warming to 2 C. Nature. 517(7533), 187190.

[56] Mehanna, M., Kiely, P.D., Call, D.F., Logan, B.E., 2010. Microbial electrodialysis cell for simultaneous water desalination and hydrogen gas production. Environ. Sci. Technol. 44(24), 9578-9583.

[57] Modestra, J.A., Babu, M.L., Mohan, S.V., 2015. Electro-fermentation of real-field acidogenic spent wash effluents for additional biohydrogen production with simultaneous treatment in a microbial electrolysis cell. Sep. Purif. Technol. 150, 308-315.

[58] Mohanakrishna, G., Mohan, S.V., Sarma, P.N., 2010. Bioelectrochemical treatment of distillery wastewater in microbial fuel cell facilitating decolorization and desalination along with power generation. J. Hazard. Mater. 177(1-3), 487-494.

[59] Mohanakrishna, G., Vanbroekhoven, K., Pant, D., 2016. Imperative role of applied potential and inorganic carbon source on acetate production through microbial electrosynthesis. J. CO2 Util. 15, 57-64.

[60] Mohanakrishna, G., Vanbroekhoven, K., Pant, D., 2018. Impact of dissolved carbon dioxide concentration on the process parameters during its conversion to acetate through microbial electrosynthesis. React. Chem. Eng. 3(3), 371-378.

[61] Njenga, M., Karanja, N., Karlsson, H., Jamnadass, R., Iiyama, M., Kithinji, J., Sundberg, C., 2014. Additional cooking fuel supply and reduced global warming potential from recycling charcoal dust into charcoal briquette in Kenya. J. Cleaner Prod. 81, 81-88.

[62] Ren, Y., Wang, T., Wang, J., 2011. Characterization of biohydrogen production by co-fermentation of glucose and xylose. J. Chem. Ind. Eng. 9.

[63] Rivera, I., Buitron, G., Bakonyi, P., Nemestothy, N., Belafi-Bako, K., 2015. Hydrogen production in a microbial electrolysis cell fed with a dark fermentation effluent. J. Appl. Electrochem. 45(11), 1223-1229.

[64] Roy, S., Schievano, A., Pant, D., 2016. Electro-stimulated microbial factory for value added product synthesis. Bioresour. Technol. 213, 129139.

[65] Rozendal, R.A., Hamelers, H.V.M., Euverink, G.J.W., Metz, S.J., Buisman, C.J.N., 2006. Principle and perspectives of hydrogen production through biocatalyzed electrolysis. Int. J. Hydrogen Energy. 31(12), 1632-1640.

[66] Rozendal, R.A., Jeremiasse, A.W., Hamelers, H.V., Buisman, C.J., 2008. Hydrogen production with a microbial biocathode. Environ. Sci. Technol. 42(2), 629-634

[67] Sadhukhan, J., Lloyd, J.R., Scott, K., Premier, G.C., Yu, E.H., Curtis, T., Head, I.M., 2016. A critical review of integration analysis of microbial electrosynthesis (MES) systems with waste biorefineries for the production of biofuel and chemical from reuse of $\mathrm{CO}_{2}$. Renew. Sust. Energy Rev. 56, 116-132.

[68] Saeed, H.M., Husseini, G.A., Yousef, S., Saif, J., Al-Asheh, S., Abu Fara, A.A., Azzam, S., Khawaga, R., Aidan, A., 2015. Microbial desalination cell technology: a review and a case study. Desalination. 359, 1-13.

[69] Schleussner, C.F., Lissner, T.K., Fischer, E.M., Wohland, J., Perrette, M., Golly, A., Rogelj, J., Childers, K., Schewe, J., Frieler, K., Mengel, M., 2016. Differential climate impacts for policy-relevant limits to global warming: the case of $1.5^{\circ} \mathrm{C}$ and $2^{\circ} \mathrm{C}$. Earth Syst. Dyn. 7(2), 327-351.

[70] Sivagurunathan, P., Kuppam, C., Mudhoo, A., Saratale, G.D., Kadier, A., Zhen, G., Chatellard, L., Trably, E., Kumar, G., 2018. A comprehensive review on two-stage integrative schemes for the valorization of dark fermentative effluents. Crit. Rev. Biotechnol. 38(6), 868-882.

[71] Sravan, J.S., Butti, S.K., Sarkar, O. and Mohan, S.V., 2019. Electrofermentation: chemicals and fuels. In: Venkata Mohan, S., Varjani, S., Pandey, A. (Eds.) Microbial electrochemical technology. Elsevier, pp. 723-737.

[72] Sun, M., Sheng, G.P., Zhang, L., Xia, C.R., Mu, Z.X., Liu, X.W., Wang, H.L., Yu, H.Q., Qi, R., Yu, T., Yang, M., 2008. An MEC-MFC-coupled system for biohydrogen production from acetate. Environ. Sci. Technol. 42(21), 8095-8100.
[73] Tartakovsky, B., Mehta, P., Bourque, J., Guiot, S.R., 2011. Electrolysis-enhanced anaerobic digestion of wastewater. Bioresour. Technol. 102(10), 5685-5691.

[74] Thygesen, A., Thomsen, A.B., Possemiers, S., Verstraete, W., 2010 Integration of microbial electrolysis cells (MECs) in the biorefinery for production of ethanol, $\mathrm{H}_{2}$ and phenolics. Waste Biomass Valori. $1(1), 9-20$.

[75] Turner, J.A., 2004. Sustainable hydrogen production. Science. 305(5686), 972-974

[76] Varanasi, J.L., Veerubhotla, R., Pandit, S., Das, D., 2019. Biohydrogen production using microbial electrolysis cell: recent advances and future prospects, in: Venkata Mohan, S., Varjani, S., Pandey, A. (Eds.), Microbial Electrochemical Technology. Elsevier, pp. 843-869.

[77] Venkata Mohan, S., Mohanakrishna, G., Raghavulu, S.V., Sarma, P.N., 2007. Enhancing biohydrogen production from chemical wastewater treatment in anaerobic sequencing batch biofilm reactor (AnSBBR) by bioaugmenting with selectively enriched kanamycin resistant anaerobic mixed consortia. Int. J. Hydrogen Energy. 32(15), 3284-3292.

[78] Venkata Mohan, S., Mohanakrishna, G., Sarma, P.N., 2008. Integration of acidogenic and methanogenic processes for simultaneous production of biohydrogen and methane from wastewater treatment. Int. J. Hydrogen Energy. 33(9), 2156-2166.

[79] Venkata Mohan, S., Chiranjeevi, P., Mohanakrishna, G., 2012. A rapid and simple protocol for evaluating biohydrogen production potential (BHP) of wastewater with simultaneous process optimization. Int. J. hydrogen Energy. 37(4), 3130-3141.

[80] Wallack, M.J., Geise, G.M., Hatzell, M.C., Hickner, M.A., Logan, B.E., 2015. Reducing nitrogen crossover in microbial reverseelectrodialysis cells by using adjacent anion exchange membranes and anion exchange resin. Environ. Sci. Water Res. Technol. 1(6), 865-873.

[81] Wan, L.L., Li, X.J., Zang, G.L., Wang, X., Zhang, Y.Y., Zhou, Q.X., 2015. A solar assisted microbial electrolysis cell for hydrogen production driven by a microbial fuel cell. RSC Adv. 5(100), 8227682281.

[82] Wang, A., Sun, D., Cao, G., Wang, H., Ren, N., Wu, W.M., Logan, B.E., 2015. Integrated hydrogen production process from cellulose by combining dark fermentation, microbial fuel cells, and a microbial electrolysis cell. Bioresour. Technol. 102(5), 4137-4143.

[83] Wünschiers, R., Lindblad, P., 2002. Hydrogen in education-a biological approach. Int. J. Hydrogen Energy. 27(11-12), 1131-1140.

[84] Yang, E., Chae, K.J., Choi, M.J., He, Z., Kim, I.S., 2019. Critical review of bioelectrochemical systems integrated with membranebased technologies for desalination, energy self-sufficiency, and highefficiency water and wastewater treatment. Desalination. 452, 40-67.

[85] Yu, Z., Leng, X., Zhao, S., Ji, J., Zhou, T., Khan, A., Kakde, A., Liu, P., Li, X., 2018. A review on the applications of microbial electrolysis cells in anaerobic digestion. Bioresour. Technol. 255, 340-348.

[86] Yuan, H., He, Z., 2015. Integrating membrane filtration into bioelectrochemical systems as next generation energy-efficient wastewater treatment technologies for water reclamation: a review. Bioresour. Technol. 195, 202-209.

[87] Yuan, H., Lu, Y., Abu-Reesh, I.M., He, Z., 2015. Bioelectrochemical production of hydrogen in an innovative pressure-retarded osmosis/microbial electrolysis cell system: experiments and modeling. Biotechnol. Biofuels. 8(1), 1-12.

[88] Zeng, X., Borole, A.P., Pavlostathis, S.G., 2015. Biotransformation of furanic and phenolic compounds with hydrogen gas production in a microbial electrolysis cell. Environ. Sci. Technol. 49(22), 13667. 13675.

[89] Zhang, Y., Angelidaki, I., 2011. Submersible microbial fuel Cell Sensor for monitoring microbial Activity and BOD in groundwater: focusing on impact of anodic biofilm on sensor applicability. Biotechnol. Bioeng. 108(10), 2339-2347. 
[90] Zhang, Y., Angelidaki, I., 2012. Innovative self-powered submersible microbial electrolysis cell (SMEC) for biohydrogen production from anaerobic reactors. Water Res. 46(8), 2727-2736.

[91] Zhang, Y., Angelidaki, I., 2013. A new method for in situ nitrate removal from groundwater using submerged microbial desalination e denitrification cell (SMDDC). Water Res. 47(5), 1827-1836.

[92] Zhang, Y., Angelidaki, I., 2014. Microbial electrolysis cells turning to be versatile technology: recent advances and future challenges. Water Res. $56,11-25$.

[93] Zhang, Y., Angelidaki, I., 2015. Counteracting ammonia inhibition during anaerobic digestion by recovery using submersible microbial desalination cell. Biotechnol. Bioeng. 112, 1478-1482.

[94] Zhen, G., Lu, X., Kumar, G., Bakonyi, P., Xu, K., Zhao, Y., 2017. Microbial electrolysis cell platform for simultaneous waste biorefinery and clean electrofuels generation: current situation, challenges and future perspectives. Prog. Energy Combust. Sci. 63, 119-145.
[95] Zhi, Z., Pan, Y., Lu, X., Zhen, G., Zhao, Y., Zhu, X., Xiong, J., Zhao, T., 2019. Electrically regulating co-fermentation of sewage sludge and food waste towards promoting biomethane production and mass reduction. Bioresour. Technol. 279, 218-227.

[96] Zhao, H., Zhang, Y., Zhao, B., Chang, Y., Li, Z., 2012. Electrochemical reduction of carbon dioxide in an MFC-MEC system with a Layer-by-Layer Self-Assembly Carbon Nanotube/cobalt phythalocyanine modified electrode. Environ. Sci. Technol. 46(9), 5198-5204.

[97] Zhou, M., Wang, H., Hassett, D.J., Gu, T., 2013. Recent advances in microbial fuel cells (MFCs) and microbial electrolysis cells (MECs) for wastewater treatment, bioenergy and bioproducts. J. Chem. Technol. Biotechnol. 88(8), 508-518.

[98] Zhu, X., Hatzell, M.C., Cusick, R.D., Logan, B.E., 2013. Microbial reverse-electrodialysis chemical-production cell for acid and alkali production. Electrochem. Commun. 31, 52-55. 